\title{
A method for estimating transpiration of irrigated urban trees in California
}

\author{
Elizaveta Litvak ${ }^{1}$, Heather R. McCarthy ${ }^{2}$, and Diane E. Pataki ${ }^{1}$, \\ ${ }^{1}$ Department of Biology, University of Utah, Salt Lake City, UT \\ ${ }^{2}$ Department of Microbiology and Plant Biology, University of Oklahoma, Norman, OK
}

Elizaveta Litvak

Department of Biology

University of Utah

257 S 1400 E rm 201

Salt Lake City, UT 84112

Email: elitvak@uci.edu

Phone: 850-644-1189

Heather R. McCarthy

Department of Microbiology and Plant Biology

770 Van Vleet Oval

University of Oklahoma

Norman, OK 73019

Email: heather.mccarthy@ou.edu

Phone: 405-325-7793

Diane E. Pataki

Department of Biology

University of Utah

257 S 1400 E rm 201

Salt Lake City, UT 84112

diane.pataki@utah.edu

Email: diane.pataki@utah.edu

Phone: 801-581-3917 


\begin{abstract}
Transpiration of urban forests in southern California is highly uncertain and challenging to quantify because of variability of tree characteristics and stomatal responses among species and locations. However, as California undergoes the most severe drought on record, it is imperative to develop approaches to estimating transpiration of irrigated urban trees $\left(E_{\text {Trees }}\right)$. We examined the landscape coefficient method recommended by the California Irrigation Management Information System (CIMIS) and widely used to estimate irrigation needs of urban landscapes. The CIMIS method uses reference evapotranspiration $\left(E T_{0}\right)$ calculated from the PenmanMonteith equation and a set of species-specific factors to adjust $E T_{0}$ for particular landscapes. We found a mismatch between CIMIS predictions and actual patterns of urban tree transpiration that we attributed to underrepresentation of tree physiological mechanisms in $E T_{0}$. As an alternative, we propose an empirical model of $E_{\text {Trees }}$ based on in situ measurements on 108 urban trees $(14$ species $)$ in the Los Angeles region: $E_{\text {Trees }}=E_{\text {ref }}\left(0.23 \ln D+0.002 I_{0}+0.55\right)$. Here $D$ is the vapor pressure deficit of the air, $I_{0}$ is incoming solar radiation and $E_{r e f}$ is species-specific parameter representing $E_{\text {Trees }}$ at $\mathrm{D}=1 \mathrm{kPa}$ that may be estimated using mean sapwood area of a tree stand. This model may be used to estimate $E_{\text {Trees }}$ for practical applications and to improve representation of irrigated urban forests in hydrologic models.
\end{abstract}




\section{Introduction}

Transpiration of urban forests in southern California is a substantial yet highly uncertain component of municipal water use (Gleick et al., 2003; Mini et al., 2014; Ngo \& Pataki, 2008; Pataki et al., 2011). Its uncertainty prevents ecohydrologic models from accurately estimating urban and regional water budgets (Howard \& Israfilov, 2002; Shields \& Tague, 2012; Vahmani \& Hogue, 2014a, 2014b) and municipal institutions from informed planning of water allocation and landscape irrigation (Gleick et al., 2003; Mini et al., 2014; Pataki, et al., 2011). Currently, southern California is undergoing the most severe drought on record and faces further water shortages (Aghakouchak et al., 2014; Diffenbaugh et al., 2015; MacDonald, 2010; Thompson, 2016; Williams et al., 2015) that highlight the need for an improved ability to model urban water fluxes (Bates et al., 2008; Hanak \& Lund, 2008; Melillo et al., 2014). In Los Angeles, the most populated city in California, more than $50 \%$ of residential water is used for landscape irrigation (Mini et al., 2014). Yet, the urban forest is still a valued component of the urban landscape and requires continuous irrigation in Los Angeles (Clarke et al., 2013; McCarthy et al., 2011; Pincetl, 2010). Under such circumstances, it is imperative to make informed decisions about water use of the urban forest. However, urban forest water use remains one of the most significant uncertainties in the urban water budget.

Available data on urban forest transpiration is very limited (Costello, 2013; Pataki et al., 2011; Renninger et al., 2009). The urban forest in Los Angeles contains about 6 million trees and is comprised of hundreds of species that are mostly non-native to southern California (Clarke et al., 2013; Gillespie et al., 2011; Nowak et al., 2010; Pataki et al., 2013). Even though these trees receive irrigation, atmospheric conditions in Los Angeles are often drier than in mesic regions, with lower relative humidity and higher vapor pressure deficit. This may result in transpiration 
patterns that are very different than in natural forests (Bush et al., 2008; Litvak et al., 2011; McCarthy \& Pataki, 2010). Moreover, species native to the region may also show different patterns of transpiration in urban settings when they receive irrigation and are subject to other unique conditions in the urban environment (Bijoor et al., 2011; Goedhart \& Pataki, 2012; McCarthy \& Pataki, 2010; Pataki et al., 2011). For example, native California sycamore (Platanus racemosa Nutt.) used substantially more water under urban irrigated conditions in Los Angeles than in a nearby natural riparian environment; furthermore, its transpiration was higher than a number of non-native irrigated urban trees in the same area (McCarthy \& Pataki, 2010; Pataki et al., 2011). According to our previous study of 14 tree species in Los Angeles area, tree transpiration $\left(E_{T}\right)$ ranged from as low as $0.8 \pm 1.2 \mathrm{~kg} \mathrm{tree}^{-1}$ day $^{-1}$ (laurel sumac, Malosma laurina (Nutt.) Nutt. Ex Abrams) to as high as $176.9 \pm 75.2 \mathrm{~kg} \mathrm{tree}^{-1}$ day $^{-1}$ (London plane, Platanus hybrida Brot.) and was highly variable among species and locations (Pataki et al., 2011). Therefore, transpiration of the urban forest in Los Angeles and its sensitivity to species composition is extremely difficult to predict.

Ecohydrologic models often use a landscape coefficient approach to account for urban forest transpiration as part of regional evapotranspiration (ET) in southern California (Spano et al., 2009; Vahmani \& Hogue, 2014a, 2014b). This approach is based on the Penman-Monteith model of surface energy balance that approximates $E T$ of a reference vegetated surface $\left(E T_{0}\right)$ (Monteith, 1965; Penman, 1948; Pereira \& Perrier, 1999; Zhang et al., 2009). The California Irrigation Management Information System (CIMIS) is a valuable resource provided by the California Department of Water Resources for using the landscape coefficient method to estimate $E T$ of actual landscapes (http://www.cimis.water.ca.gov). CIMIS utilizes a set of 145 meteorological stations across California that are placed on irrigated turfgrass that serves as a 
reference surface for $E T_{0}$. CIMIS reports hourly and daily values of $E T_{0}$ calculated with a version of the Penman-Monteith equation:

$$
E T_{0}=\frac{\Delta / \lambda}{\Delta+\gamma\left(1+C u_{2}\right)}\left(R_{n}-G\right)+\frac{\gamma\left(\frac{37}{T_{a}+273.16}\right) u_{2}}{\Delta+\gamma\left(1+C u_{2}\right)} D
$$

where $T_{a}$ is air temperature, $\Delta$ is the slope of the saturation vapor pressure versus $T_{\mathrm{a}}$ at current $T_{a}$, $\lambda$ is the latent heat of vaporization, $\gamma$ is the psychrometric constant, $C$ is the surface and aerodynamic resistance coefficient, $u_{2}$ is a predefined linear function of wind speed at $2 \mathrm{~m}$ height, $R_{n}$ is net radiation, $G$ is the soil heat flux, and $D$ is the vapor pressure deficit of the air (http://www.cimis.water.ca.gov/Content/PDF/PM\%20Equation.pdf).

To calculate $E T$ from a particular landscape, $E T_{0}$ is multiplied with a landscape coefficient $k_{L}$ (Allen et al., 1998; Pereira \& Perrier, 1999; Spano et al., 2009):

$$
E T=k_{L} E T_{0}
$$

In addition to modeling large-scale $E T$, the landscape coefficient method is routinely used by landscape managers for practical assessment of urban irrigation requirements (California Department of Water Resources, 2009; City of Los Angeles Department of City Planning, 2011). For this purpose, $k_{L}$ is expressed as a product of three factors:

$$
k_{L}=k_{s} k_{d} k_{m c}
$$

where $k_{S}$ is intended to correct for species-specific differences in transpiration, $k_{d}$ for planting density, and $k_{m c}$ for micro-climatic conditions (Costello et al., 2000).

To estimate ET of many tree species planted in California, look-up table values of $k_{S}$ are provided (Costello et al., 2000). However, the performance of the landscape coefficient method 
and the values of $k_{S}$ have never been tested against in situ tree transpiration in the Los Angeles area (Costello et al., 2000).

The first of the two goals of this study is to evaluate the landscape coefficient method using an in situ dataset of urban tree transpiration in the greater Los Angeles area (Fig. 1; Pataki et al., 2011). The landscape coefficient method was developed for agricultural ecosystems and has been supported by extensive research that refined landscape coefficients for crop fields (Allen et al., 1998). However, extensive surfaces of crop fields covered by a single species of uniform height are quite different from canopies of urban trees (Spronken-Smith et al. 2000, Jansson et al. 2006, Hagishima et al. 2007, Rim 2009). Even though $k_{L}$ is applied to adjust for differences between $E T_{0}$ and landscape $E T$, it is not based on physiology of urban trees or mechanisms underlying differences in transpiration among species (Sinclair et al., 2014; Zeppel, 2013). Therefore, our second goal is to propose an alternative approach to estimating tree transpiration based on general patterns in urban tree transpiration in response to environmental factors.

Previous studies have shown that $E_{T}$ is correlated with the logarithm of atmospheric vapor pressure deficit measured within tree canopies $\left(D_{T}\right)$ :

$$
E_{T}=E_{\text {Tref }}+m_{T} \ln \left(D_{T}\right)
$$

with the coefficients $E_{\text {Tref }}$ and $m_{T}$ being proportional to each other and to the vulnerability of tree branches to cavitation (Litvak et al., 2012). This relationship has a fundamental physiological basis: trees with more sensitive stomatal regulation consistently demonstrate higher stomatal conductance and transpiration at relatively low $D_{T}$ (Katul et al., 2009; Oren et al., 1999). In addition to the established relationship with $D_{T}$ in equation 4 , transpiration of more than half of 
studied tree species in the Los Angeles region showed a linear correlation with the intensity of solar radiation measured either onsite or by the closest CIMIS weather stations (Litvak et al., 2011, 2012; McCarthy \& Pataki, 2010). However, the resulting model coefficients were site- and species-specific and highly variable. Here, we aimed to evaluate more general patterns that can provide a robust measurement-based alternative to the current method of estimating $E T$ from the

landscape coefficient method. This model should systematize the variability of transpirational patterns found in previous studies (Litvak et al., 2011, 2012; McCarthy \& Pataki, 2010; Pataki et al., 2011) and be practically applicable; i.e. model parameters should be easily accessible by landscape managers. This work is a necessary step toward a more accurate, systematic technique to calculate urban tree transpiration that will assist landscape managers and help improve regional ecohydrologic models.

\section{Methods}

\section{Dataset of tree transpiration}

Tree transpiration was measured in the Los Angeles metropolitan area of California. The climate is semi-arid, with mean annual temperature of $18.6^{\circ} \mathrm{C}$ and annual precipitation of 37.9 cm (Western Regional Climate Center, http://www.wrcc.dri.edu), currently shifting to warmer and drier conditions (Diffenbaugh et al., 2015; MacDonald, 2010; Melillo et al., 2014). The precipitation is mostly winter rain, and all measurement locations were sustained by irrigation during growing season.

We used a dataset of transpiration of 14 species of urban trees commonly planted in the Los Angeles region. The trees were located on the campus of the University of California ("Irvine"), the California State University Fullerton Arboretum ("Fullerton"), the Los Angeles 
County Arboretum and Botanic Garden ("LA Arboretum"), a city street ("Sycamore Ave"), the Los Angeles Zoo and Botanical Garden ("LA Zoo"), and the Los Angeles Police Revolver and Athletic Club ("Police Academy"). The majority of sites were irrigated by automatic sprinklers (Litvak et al., 2014; Litvak et al., 2011; McCarthy \& Pataki, 2010). For this study, we chose only datasets in which $E_{T}$ had very weak or no response to changes in soil moisture and did not decrease at high $D$, which implies that the trees had access to abundant soil water and were not water stressed. In other words, tree stands were selected based on the absence of soil water stress, without consideration of particular irrigation regimes. The characteristics of study sites and trees are shown in Table 1.

We estimated transpiration of individual trees $\left(E_{T}, \mathrm{~kg} \mathrm{~d}^{-1}\right)$ from sap flux measurements made in the years 2007 and 2008. Thermal dissipation probes (Granier, 1987) were installed in sapwood of studied trees in the spring of each year, and provided continuous data until the removal of the probes the following winter. We calculated $E_{T}$ using generic functions of sap flux distribution within sapwood as described by Pataki et al. (2011). The resulting whole-tree transpiration was

$E_{T} \approx 6.8 \times 10^{-4} A_{S} J_{0}$ for angiosperm trees $\left(\mathrm{R}^{2}=0.95 ; \mathrm{p}<0.0001\right)$, and

$E_{T} \approx 6.4 \times 10^{-4} A_{S} J_{0}$ for gymnosperm trees $\left(\mathrm{R}^{2}=0.99 ; \mathrm{p}<0.0001\right)$

where $A_{S}\left(\mathrm{~cm}^{2}\right)$ is sapwood area and $J_{0}\left(\mathrm{~g} \mathrm{~cm}^{-2} \mathrm{~d}^{-1}\right)$ is sapflux density in the outer $2 \mathrm{~cm}$ of sapwood that was measured in situ. For deciduous trees, we only used the data collected before the beginning of leaf senescence in November. More details about sap flux data collection and processing can be found in Pataki et al. (2011) and Litvak et al. (2012). 
Studied trees had open canopies and their planting densities varied from 86 to 222 trees $\mathrm{ha}^{-1}$ (Table 1), with the median value of 108 trees $\mathrm{ha}^{-1}$.Planting densities were within $10 \%$ of 100 trees/ha at half of the sites and within $25 \%$ at $75 \%$ of the sites. Other tree species were often present at the same sites, so that the actual densities of tree stands were closer to 200 trees $^{-1} a^{-1}$. We calculated species-specific transpiration of each tree stand in $\mathrm{mm} \mathrm{d}^{-1}\left(E_{\text {Trees }}\right)$ using average $E_{T}$ of each species at each site and assuming a standardized planting density of 100 trees $^{-1}{ }^{-1}$ :

$$
E_{\text {Trees }}=\frac{0.01 \times 10^{3}}{\rho_{\mathrm{H}_{2}} \mathrm{O}} E_{T}=0.01 E_{T}
$$

Here, 0.01 is the tree density of 100 trees ha $^{-1}$ in trees $\mathrm{m}^{-2}, 10^{3}$ converts $\mathrm{m}$ to $\mathrm{mm}$, and $\rho_{\mathrm{H} 2 \mathrm{O}} \approx 10^{3}$ $\mathrm{kg} \mathrm{m}^{-3}$ is the density of water. $E_{\text {Trees }}$ represents transpiration of single species stands of similar tree densities, allowing for a comparison between the contributions of different tree species to plot level transpiration. Stand transpiration of any tree density can be easily estimated from $E_{\text {Trees. }}$.

The performance of the landscape coefficient method

To test how CIMIS $E T_{0}$ is related to $E_{\text {Trees, }}$ we utilized the data from CIMIS weather stations closest to each study site (Table 1). We downloaded daily values of $E T_{0}$ from CIMIS for each period of in situ measurements. We plotted $E_{\text {Trees }}$ against $E T_{0}$ and fitted the following linear equation:

$$
E_{\text {Trees }}=k_{L} E T_{o}
$$

where $k_{L}$ are landscape coefficients by definition (Eq. 2). We performed a series of linear regressions with zero origin to obtain $k_{L}$ for each species as a regression coefficient (Eq. 7). We 
looked for the consistency between the values of $k_{L}$ at different sites in order to test their suitability for estimating $E_{\text {Trees }}$.

An empirical model with environmental parameters from CIMIS

In addition to $E T_{0}$, we downloaded daily values of the intensity of solar radiation $\left(I_{0}\right)$, air temperature, and water vapor pressure from the closest CIMIS weather station to each study site (Table 1) for each period of in situ ET measurements. We used air temperature and vapor pressure to calculate the vapor pressure deficit of the air $(D)$. Then we built a model for $E_{\text {Trees }}$ in two steps. First, we modeled $E_{\text {Trees }}$ of each single-species group of trees as a linear function of $\ln D$ similar to Litvak et al. (2012) (Eq. 4):

$$
E_{\text {Trees }}=E_{\text {ref }}+m_{D} \ln D
$$

where $E_{r e f}\left(\mathrm{~mm} \mathrm{~d}^{-1}\right)$ is theoretical transpiration of a single species stand with the density of 100 trees ha ${ }^{-1}$ at daily average $D$ of $1 \mathrm{kPa}$ and $m_{D}\left(\mathrm{~mm} \mathrm{~d}^{-1} \ln (\mathrm{kPa})^{-1}\right)$ is the sensitivity of $E_{\text {Trees }}$ to $D$. Then, we tested for a correlation between the residuals from Eq. 8 and $I_{0}$ :

$$
\text { residuals }=\Delta E_{\text {ref }}+m_{I} I_{0} \text {. }
$$

where $\Delta E_{\text {ref }}\left(\mathrm{mm} \mathrm{d}^{-1}\right)$ is an intercept term and $m_{I}\left(\mathrm{~mm} \mathrm{~d}^{-1}\left(\mathrm{~W} / \mathrm{m}^{2}\right)^{-1}\right)$ is the sensitivity of $E_{\text {Trees }}$ to $I_{0}$. We decided to use $I_{0}$ rather than $R_{n}$ because it is easier to measure on site and was shown to be proportional to $R_{n}$ in multiple studies (Davies, 1967; Hu et al., 2012; Iziomon et al., 2000;

Kozlowski, 1981; Li \& Barnes, 1980; Marková et al., 2006). The ultimate model for $E_{\text {Trees }}$ is the combination of Eq. 8 and 9:

$$
E_{\text {Trees }}=E_{\text {ref }}+m_{D} \ln D+\Delta E_{\text {ref }}+m_{I} I_{0} .
$$


A major challenge of modeling urban forest transpiration is that different stomatal responses cause great variability of species- and location-specific model coefficients (Litvak et al., 2012). However, $E_{r e f}$ and $m_{D}$ are linearly correlated due to intrinsic coordination of stomatal sensitivity to $D$ with stomatal conductance at $1 \mathrm{kPa}$ (Katul et al., 2009; Litvak et al., 2012; Oren et al., 1999). Here, we hypothesize that $\Delta E_{r e f}$ and $m_{I}$ may also be correlated with $E_{r e f}$ because stomatal responses to $D$ and $I_{0}$ are inter-related. This would simplify Eq. 10 by reducing the number of independent coefficients. Finally, we used the proportionality of tree transpiration to $A_{S}$ (Eq. 5) to complete the model.

Relative weights of atmospheric and radiative drivers of $E_{\text {Trees }}$

To assess the relative importance of atmospheric $(D)$ and radiative $\left(I_{0}\right)$ terms in driving $E_{\text {Trees }}$, we calculated a "decoupling factor" $(0 \leq \Omega \leq 1)$. The lower the value of $\Omega$, the higher role of $D$ in determining transpiration (Jarvis \& McNaughton, 1986). We estimated $\Omega$, considering $E_{\text {Trees }}$ as the sum of the "equilibrium term" $\left(E_{\text {eq }}\right)$ driven by radiative energy and an "imposed term" $\left(E_{\text {imp }}\right)$ driven by the ambient air (Jarvis \& McNaughton, 1986; Smith \& Jarvis, 1998):

$E_{\text {Trees }}=\Omega E_{e q}+(1-\Omega) E_{\text {imp }}$.

We calculated $E_{e q}$ as

$E_{e q}=\frac{\Delta}{\Delta+\gamma} \frac{R_{n}}{\lambda}$

where $\lambda=2.45 \mathrm{MJ} \mathrm{kg}^{-1}$ is the latent heat of vaporization (Smith \& Jarvis, 1998). Then, we estimated $\Omega$ as

$\Omega=\frac{\Delta E_{r e f}+m_{I} I_{0}}{E_{e q}}$

where the radiative term in the numerator is from Eq. 10. 


\section{Statistics}

We evaluated seasonal changes in the data from CIMIS weather stations using repeated measures analysis of variance (ANOVA) and Tukey's honest significance test. We used R software (version 2.10.1, the R Foundation for Statistical Computing, http://www.r-project.org) to perform the statistical tests. For curve fitting and regression analysis of tree transpiration, we used Regression Wizard in SigmaPlot version 10.0 (Systat Software 2006).

\section{Results}

Tree transpiration and weather data

In situ tree transpiration and corresponding weather data from CIMIS stations are shown on Fig. 2-3. $E_{\text {Trees }}$ had different ranges of values depending on species and location, from $0.06 \pm$ $0.02 \mathrm{~mm} \mathrm{~d}^{-1}$ (laurel sumac at LA Zoo, Fig. 3) to $2.59 \pm 1.76 \mathrm{~mm} \mathrm{~d}^{-1}$ (London planetree at Sycamore Ave, Fig. 3). Clear seasonal patterns of $E_{\text {Trees }}$ were not always present.

$E T_{0}$ varied from $0.04 \mathrm{~mm} \mathrm{~d}^{-1}$ (station \#78 Pomona, 12/22/2008) to $7.44 \mathrm{~mm} \mathrm{~d}^{-1}$ (station \#99 Santa Monica, 5/6/2007). Seasonal differences of $E T_{0}$ (summer versus winter) were always highly significant (repeated measures ANOVA, $\mathrm{p}<0.0001$ ). $I_{0}$ was proportional to $E T_{0}$ (least square regression, $\mathrm{p}<0.0001, \mathrm{R}_{\text {adj }}^{2}=0.77-0.97$, not shown). $D$ varied from $\sim 0.02 \mathrm{kPa}$ to $\sim 3$ $\mathrm{kPa}$, reaching the maxima of $3.09 \mathrm{kPa}$ on 10/23/2007 and $3.33 \mathrm{kPa}$ on 11/15/2008 (station \#75 Irvine for both).

\section{Landscape coefficients}

The landscape coefficient method implies proportionality between $E_{\text {Trees }}$ and $E T_{0}$ (Eq. 2). However, $E_{\text {Trees }}$ was proportional to $E T_{0}$ for the majority but not all tree species (Fig. 4). $E_{\text {Trees }}$ of London planetree, California sycamore, Chinese elm (Ulmus parvifolia Jacq.), lacebark tree 
(Brachychiton discolor F. Muell.), kurrajong (Brachychiton populneus (Scott \& Endl.) R. Br.), crape myrtle (Lagerstroemia indica L.), goldenrain tree (Koelreuteria paniculata Laxm.), coast redwood (Sequoia sempervirens (D. Don) Endl.) and honey locust (Gleditsia triacanthos L.) was proportional to $E T_{0}$ (linear regressions with zero origin; $0.09<\mathrm{R}_{\mathrm{adj}}{ }^{2}<0.70$; $\mathrm{p}<0.0001$ ). $E_{\text {Trees }}$ of Chinese banyan (Ficus microcarpa L. f.), laurel sumac, rose gum (Eucalyptus grandis W. Hill ex Maiden) and blue jacaranda (Jacaranda mimosifolia D. Don) was not proportional to $E T_{0}$ (linear regressions with zero origin; $\mathrm{R}_{\mathrm{adj}}{ }^{2}=0$ ). Finally, $E_{\text {Trees }}$ of Canary Island pine (Pinus canariensis C. Sm.) - present at two different locations - was proportional to $E T_{0}$ at one location (linear regressions with zero origin; Irvine, $\mathrm{R}_{\mathrm{adj}}{ }^{2}=0.41 ; \mathrm{p}<0.0001$ ) and not proportional at the other (Police Academy, $\mathrm{R}_{\mathrm{adj}}{ }^{2}=0$ ). $k_{L}$ calculated from the regressions varied from 0.03 to 0.22 and were not systematically related to recommended values of $k_{S}$ (Table 2). Relationships between $E_{\text {Trees }}$ and $I_{0}$ were essentially similar to the relationships between $E_{\text {Tres }}$ and $E T_{0}$, with $E_{\text {Trees }}$ being proportional to $I_{0}$ whenever it was proportional to $E T_{0}$ and vice versa (not shown).

An empirical model of tree transpiration

$E_{\text {Trees }}$ was linearly correlated with $\ln (D)$ for all tree species; $\mathrm{R}_{\text {adj }}{ }^{2}$ of the linear regressions (Eq. 8) varied from 0.04 to 0.49 (Fig. 5). Residuals of the regression are shown in Fig.6; the majority was linearly correlated with $I_{0}\left(\mathrm{R}_{\mathrm{adj}}^{2}\right.$ from 0.02 to 0.68$)$. The coefficients of both regressions, $E_{r e f}, \Delta E_{r e f}, m_{D}$ and $m_{I}$ (Fig. 5 and 6) are shown in Table 2. The coefficients were linearly correlated with each other (Fig. 7) reducing Eq. 10 to

$$
E_{\text {Trees }}=E_{\text {ref }}\left(1+0.23 \ln D-0.45+0.002 I_{0}\right) \text {. }
$$

$E_{\text {Trees }}$ modeled with Eq. 14 was in good correspondence with $E_{\text {Trees }}$ measured in situ (Fig. 8; $E_{\text {ref }}$ and $\mathrm{R}_{\mathrm{adj}}{ }^{2}$ are listed in Table 2; $\mathrm{p} \leq 0.0009$ for all). 
Because tree transpiration was proportional to $A_{S}$ (Eq. 5), we approximated $E_{r e f}$ using mean $A_{S}$ of each tree stand (Fig. 9):

$E_{\text {ref }} \approx 0.0012 A_{S}$ for angiosperm trees, and

$E_{r e f} \approx 0.0004 A_{S}$ for gymnosperm trees.

The ultimate equation for $E_{\text {Trees }}$ as a function of $D$ and $I_{0}$ from CIMIS and $A_{S}$ measured in situ is:

$E_{\text {Trees }}=0.0012 A_{S}\left(0.55+0.23 \ln D+0.002 I_{0}\right)$ for angiosperm trees, and

$E_{\text {Trees }}=0.0004 A_{S}\left(0.55+0.23 \ln D+0.002 I_{0}\right)$ for gymnosperm trees.

\section{Decoupling factor}

We estimated $E_{e q}$ and $\Omega$ using Eq. 11-13 for typical summer conditions in our dataset (daytime average $R_{n}=373 \mathrm{~W} \mathrm{~m}^{-2}, I_{0}=300 \mathrm{~W} \mathrm{~m}^{-2}$, and $\left.\Delta=0.19\right)$ and the parameters $\Delta E_{\text {ref }}$ and $m_{I}$ from Table 2. The resulting $E_{e q} \approx 4.9 \mathrm{~mm} \mathrm{~d}^{-1}$ and $\Omega$ varies from zero to 0.06 (Table 2).

\section{Discussion}

\section{Drivers of urban tree transpiration and landscape coefficient method}

In the present study, as well as in previous studies, $D$ and $I_{0}$ were the most important environmental drivers of $E_{\text {Trees }}$ provided that soil moisture is non-limiting (Litvak et al., 2011;

McCarthy \& Pataki, 2010). If soil water supply was inadequate, it would affect $E_{\text {Trees }}$ along with atmospheric drivers by influencing plant water potential, causing water stress and inducing stomatal closure. We consider $D$ as the atmospheric driving force of plant transpiration because it approximates the gradient of vapor pressure between leaf surfaces and bulk atmosphere, and $I_{0}$ as a radiative parameter approximating the amount of solar energy that reaches transpiring surfaces. 
The relative importance of atmospheric and radiative forces in driving transpiration depends on the degree of coupling between the canopy and bulk atmosphere. Tree canopies have relatively high aerodynamic roughness that promotes turbulent mixing of the air adjacent to leaves with the surrounding atmosphere. Therefore, tree canopies are usually well coupled with atmospheric conditions, which makes stomatal regulation an important control of gradients across leaf surfaces (Aranda et al., 2012; Jarvis \& McNaughton, 1986). Our results indicate that the urban, open-canopied forest in the Los Angeles area is very coupled with the atmosphere ( $\Omega$ $\leq 0.06$ ). Values of $\Omega<0.2$ were previously reported for urban forests (Chen et al., 2011) and natural forests under non-stressful conditions (Jarvis \& McNaughton, 1986), as well as $0.06 \leq \Omega$ $\leq 0.38$ in the upper part of a deciduous forest canopy (Köstner et al., 1992).

In contrast, $\Omega$ of crops and grasslands varies from 0.4 to 0.9 , which indicates a high degree of decoupling from atmospheric conditions (Jarvis \& McNaughton, 1986). These canopies have low aerodynamic roughness and are decoupled from atmospheric conditions by a thick adjacent layer of humid air. Transpiration of such canopies depends on $R_{n}$ as a major driver, with $D$ outside the boundary layer playing a secondary role (Collatz et al., 1991; Jarvis \& McNaughton, 1986). The landscape coefficient method was developed for such decoupled systems (Allen et al., 1998). Therefore, the relative weights of radiative and atmospheric components that determine $E T_{0}$ (decoupled canopy) are the opposite of $E_{\text {Trees }}$ (coupled canopy). For comparison, we used the data from CIMIS station \# 75 ("Irvine") for a summer day with typical weather conditions ( $15 \mathrm{July} 2008 ; I_{0}=311 \mathrm{~W} \mathrm{~m}^{-2}, T_{a}=22.6{ }^{\circ} \mathrm{C}$, and $D=0.84 \mathrm{kPa}$ ). We calculated radiative and atmospheric components of $E_{\text {Trees }}$ and $E T_{0}$ using Eq. 10 and Eq. 1 correspondingly. The relative weights of these components were on average 1:9 for $E_{\text {Trees }}$ and 9:1 for $E T_{0}$. This illustrates that $E_{\text {Trees }}$ and $E T_{0}$ are the two extremes of the range of atmospheric 
coupling. While open canopies of urban trees are almost fully coupled with the bulk air, flat turfgrass lawns are almost fully decoupled. Therefore, the proportionality between $E_{\text {Trees }}$ and $E T_{0}$ (Eq. 2) is not necessarily detectable (Fig. 4) as it may depend on fractions of $E_{\text {Trees }}$ smaller than its standard error.

The proportionality between $E_{\text {Trees }}$ and $E T_{0}$ was species-specific. Tree species studied at more than one location, California sycamore (PLRA), coast redwood (SESE), rose gum (EUGR) and blue jacaranda (JAMI) showed similar patterns in terms of presence or lack of proportionality between $E_{\text {Trees }}$ and $E T_{0}$ (Fig. 4). The only exception was Canary Island pine (PICA, Fig. 4), which showed proportionality between $E_{\text {Trees }}$ and $E T_{0}$ at Irvine but not at Police Academy. However, the pine trees at Police Academy were the oldest in the study and much older than the pines at Irvine ( 70 y.o. versus $\sim 40$ y.o.). Their canopy characteristics may have dramatically changed with age, along with hydraulic responses (Irvine et al., 2004; Köstner et al., 2002; Martínez-Vilalta et al., 2007; Valladares \& Niinemets, 2008). In addition, almost all tree species whose $E_{\text {Trees }}$ was not proportional to $E T_{0}$ had either low or no shade tolerance (with the exception of the pines mentioned above and laurel sumac that had very low transpiration, Fig. 2). This suggests that shade-intolerant trees may form sparser, more extended and aerodynamically rougher canopies under open-grown conditions (Valladares \& Niinemets, 2008).

We compared sapwood area specific landscape coefficients $\left(k_{L} / A_{S}\right.$, calculated from regressions for all tree species whose $E_{\text {Trees }}$ was proportional to $E T_{0}$ ), with recommended $k_{S}$ values (Table 2). The coefficients were in general agreement for Chinese elm and California sycamore (medium water use), and kurrajong, lacebark tree and Canary Island pine (low water use). However, the coefficients were not in agreement for goldenrain tree, London planetree, and coast redwood. In fact, the recommended coefficients were subjective estimates "based largely 
on field observations rather than scientific data" (Costello et al., 2000). To our knowledge, the $k_{L}$ estimates shown in Table 2 are the first set of landscape coefficients for trees in Los Angeles based on in situ measurements. However, as discussed above, the landscape coefficient method has an important disadvantage for estimating transpiration of urban trees. The applicability of

this method is uncertain and limited by the essential difference between sensitivities of $E_{\text {Trees }}$ and $E T_{0}$ to environmental drivers. In this study, we propose an alternative model that is consistent with physiological mechanisms controlling transpirational responses (Katul et al., 2009; Oren et al., 1999).

The model of tree transpiration

Our empirical model approximates $E_{\text {Trees }}$ using $D$ and $I_{0}$ from CIMIS weather stations and in situ $A_{S}$ estimates (Eq. 14-15). Due to the correlation between model coefficients, the ultimate model depends on a single coefficient, $E_{\text {ref }}$ that represents stand transpiration at average daily $D$ $=1 \mathrm{kPa}$. The proportionality of model coefficients (Fig. 7) is not a coincidence. By and large, regardless of the nature of its driving force, transpiration is proportional to the total conductance for water vapor between the canopy and bulk air. This is manifested in the identical coefficients in denominators of both terms of the Penman-Monteith equation (Eq. 1). Moreover, because our model is an empirical analog of the Penman-Monteith equation (with separated atmospheric and radiative components), its coefficients should also be proportional to $k_{L}$. Indeed, $E_{r e f}$ and $k_{L}$ shown in Table 2 are proportional to each other, with the coefficient of proportionality $=0.21$, $R_{a d j}^{2}=0.98$, and $\mathrm{p}<0.0001$. This proportionality of coefficients is a clear link between the landscape coefficient method and our model for $E_{\text {Trees }}$ that can be used for future adjustments and improvements in the methodology. 
$E_{r e f}$ is the key parameter of the proposed model (Eq. 14). It depends on species-specific stomatal behavior and hydraulic constraints (Litvak et al., 2012; Oren et al., 1999). In our previous study, we found a correlation between $E_{r e f}$ and vulnerability of tree branches to cavitation that was also dependent on wood porosity (ring-porous or diffuse-porous; Litvak et al., 2012). The ability to estimate $E_{r e f}$ without laboratory measurements (necessary for quantifying vulnerability to cavitation) would greatly simplify the logistics. However, this approach has two important limitations. First and the most important limitation is that $A_{S}$ does not explain $E_{\text {ref }}$ variability caused by species differences. Second, we have just a few data points available for conifers, with a binomial distribution of $A_{S}$. Therefore, the equations for gymnosperm trees (Eq. $15 \mathrm{~b}$ and $15 \mathrm{~d}$ ) may not reflect actual relationships and should be considered with caution.

\section{Conclusions}

We conclude that the landscape coefficient method in its current state does not adequately capture the dynamics of urban tree transpiration. We found that $E T_{0}$, which is mainly determined by radiative term (Eq. 1), was not proportional to $E_{\text {Trees }}$ of all studied tree species, which is primarily driven by $D$ (Fig. 5). Therefore, improving $k_{L}$ recommendations is not an effective method of better estimating $E_{\text {Trees }}$. As an alternative, we proposed an empirical model that approximates tree transpiration of all measured urban trees (Eq. 14). The model is based on in situ measurements of $E_{\text {Trees }}$ and established empirical relations that are linked to plant physiological mechanisms (Jarvis \& McNaughton, 1986; Katul et al., 2009; Litvak et al., 2012; Oren et al., 1999). The model depends on two environmental parameters measured at CIMIS weather stations ( $D$ and $\left.I_{0}\right)$ and one physiological parameter $\left(E_{r e f}\right)$ that may be estimated using mean $A_{S}$ of a tree stand (Eq. 15a and b). Therefore, the model does not demand specialized equipment or meteorological measurements on site. Hence, this model may be used by landscape 
managers for estimating water needs by urban trees. If desired, it may be used for developing an "urban tree version" of the Penman-Monteith equation by capitalizing on the fact that $E_{r e f}$, the key model coefficient, is proportional to $k_{L}$. Moreover, the model may be applied to scaling up urban forest transpiration in Los Angeles and examining its sensitivity to environmental changes and species composition. More research is needed to test the generality of our specific model coefficients to other regions; however, with in situ data for a given urban region, the general approach should be applicable. 


\section{References}

Aghakouchak, A., Feldman, D., Stewardson, M. J., Saphores, J.-D., Grant, S., \& Sanders, B. (2014). Australia’s Drought: Lessons for California. Science, 343, 1430-1431.

Allen, R. G., Pereira, L. S., Raes, D., \& Smith, M. (1998). Crop evapotranspiration - Guidelines for computing crop water requirements - FAO Irrigation and drainage paper No. 56. FAO Food and Agriculture Organization of the United Nations, Rome. Rome: FAO - Food and Agriculture Organization of the United Nations.

Aranda, I., Forner, A., Cuesta, B., \& Valladares, F. (2012). Species-specific water use by forest tree species: From the tree to the stand. Agricultural Water Management, 114, 67-77. doi:10.1016/j.agwat.2012.06.024

Bates, B., Kundzewitcz, Z. W., Wu, S., \& Palutikof, J. (2008). Climate change and water: IPCC Technical Paper VI. Intergovernmental Panel on Climate change (Vol. 403). doi:10.1016/j.jmb.2010.08.039

Bijoor, N. S., McCarthy, H. R., Zhang, D., \& Pataki, D. E. (2011). Water sources of urban trees in the Los Angeles metropolitan area. Urban Ecosystems, 15(1), 195-214. doi:10.1007/s11252-011-0196-1

Bush, S. E., Pataki, D. E., Hultine, K. R., West, A. G., Sperry, J. S., \& Ehleringer, J. R. (2008). Wood anatomy constrains stomatal responses to atmospheric vapor pressure deficit in irrigated, urban trees. Oecologia, 156, 13-20. doi:10.1007/s00442-008-0966-5

California Department of Water Resources, 2009. California Code of Regulations. Title 23. Waters. Chapter 2.7. Model Water Efficient Landscape Ordinance. Available at http://ccr.oal.ca.gov 
Chen, L., Zhang, Z., Li, Z., Tang, J., Caldwell, P., \& Zhang, W. (2011). Biophysical control of whole tree transpiration under an urban environment in Northern China. Journal of Hydrology, 402(3-4), 388-400. doi:10.1016/j.jhydrol.2011.03.034

Choat, B., Ball, M. C., Luly, J. G., \& Holtum, J. A. M. (2005). Hydraulic architecture of deciduous and evergreen dry rainforest tree species from north-eastern Australia. Trees, 19(3), 305-311. doi:10.1007/s00468-004-0392-1

City of Los Angeles Department of City Planning, 2011. City of Los Angeles Irrigation Guidelines, Local Implementation of AB 1881.

Clarke, L. W., Jenerette, G. D., \& Davila, A. (2013). The luxury of vegetation and the legacy of tree biodiversity in Los Angeles, CA. Landscape and Urban Planning, 116(5), 48-59. doi:10.1016/j.landurbplan.2013.04.006

Collatz, G. J., Ball, J. T., Grivet, C., \& Berry, J. A. (1991). Physiological and environmental regulation of stomatal conductance, photosynthesis and transpiration: a model that includes a laminar boundary layer. Agricultural and Forest Meteorology, 54, 107-136. doi:10.1016/0168-1923(91)90002-8

Costello, L. R. (2013). Urban trees and water: An overview of studies on irrigation needs in the western United States and a discussion regarding future research. Arboriculture and Urban Forestry, 39(3), 132-135.

Costello, L. R., Matheny, N., Clark, J., \& Jones, K. (2000). A guide to estimating irrigation water needs of landscape plantings in California. The landscape coefficient method and WUCOLS III. Sacramento, CA: University of California Cooperative Extension; California Department of Water Resources. 
Davies, J. A. (1967). A note on the relationship between net radiation and solar radiation. Quarterly Journal of the Royal Meteorological Society, 93(395), 109-115. doi:10.1002/qj.49709339511

Diffenbaugh, N. S., Swain, D. L., \& Touma, D. (2015). Anthropogenic warming has increased drought risk in California. Proceedings of the National Academy of Sciences, 112(13), 201422385. doi:10.1073/pnas.1422385112

Gillespie, T. W., Pincetl, S., Brossard, S., Smith, J., Saatchi, S., Pataki, D. E., \& Saphores, J.-D. (2011). A time series of urban forestry in Los Angeles. Urban Ecosystems, 15(1), 233-246. doi:10.1007/s11252-011-0183-6

Gleick, P. H., Haasz, D., Henges-Jeck, C., Srinivasan, V., Wolff, G., Cushing, K. K., \& Mann, A. (2003). Waste not, want not: the potential for urban water conservation in California. (N. L. Cain, Ed.). Oakland, CA: Pacific Institute for Studies in Development, Environment, and Security.

Goedhart, C. M., \& Pataki, D. E. (2012). Do arid species use less water than mesic species in an irrigated common garden? Urban Ecosystems, 15(1), 215-232. doi:10.1007/s11252-0110201-8

Granier, A. (1987). Evaluation of transpiration in a Douglas-fir stand by means of sap flow measurements. Tree Physiology, 3(4), 309-320. doi:10.1093/treephys/3.4.309

Hagishima, A., Narita, K., \& Tanimoto, J. (2007). Field experiment on transpiration from isolated urban plants. Hydrological Processes, 21(9), 1217-1222. doi:10.1002/hyp.6681

Hanak, E., \& Lund, J. (2008). Adapting California's water management to climate change. Preparing California for a Changing Climate. Public Policy Institute of California, San 
Francisco, CA.

Howard, K. W. F., \& Israfilov, R. G. (2002). Current Problems of Hydrogeology in Urban Areas, Urban Agglomerates and Industrial Centers. In Proceedings of the NATO Advanced Research Workshop on Current Problems on Hydrogeology in Urban Areas, Urban Agglomerates and Industrial Centers. Baku, Azerbaijan: Kluwer Academic Publishers.

Hu, B., Wang, Y., \& Liu, G. (2012). Relationship between net radiation and broadband solar radiation in the Tibetan Plateau. Advances in Atmospheric Sciences, 29(1), 135-143. doi:10.1007/s00376-011-0221-6

Irvine, J., Law, B. E., Kurpius, M. R., Anthoni, P. M., Moore, D., \& Schwarz, P. A. (2004). Agerelated changes in ecosystem structure and function and effects on water and carbon exchange in ponderosa pine. Tree Physiology, 24(7), 753-763. doi:10.1093/treephys/24.7.753

Iziomon, M. G., Mayer, H., \& Matzarakis, A. (2000). Empirical models for estimating net radiative flux: a case study for three mid-latitude sites with orographic variability. Astrophysics and Space Science, 273, 313-330.

Jansson, C., Jansson, P.-E., \& Gustafsson, D. (2006). Near surface climate in an urban vegetated park and its surroundings. Theoretical and Applied Climatology, 89(3-4), 185-193. doi:10.1007/s00704-006-0259-z

Jarvis, P. G., \& McNaughton, K. G. (1986). Stomatal Control of Transpiration: Scaling Up from Leaf to Region. Advances in Ecological Research, 15, 1-49. doi:10.1016/S00652504(08)60119-1

Katul, G. G., Palmroth, S., \& Oren, R. (2009). Leaf stomatal responses to vapour pressure deficit 
under current and $\mathrm{CO} 2$-enriched atmosphere explained by the economics of gas exchange. Plant, Cell \& Environment, 32(8), 968-79. doi:10.1111/j.1365-3040.2009.01977.x

Köstner, B., Falge, E., \& Tenhunen, J. D. (2002). Age-related effects on leaf area/sapwood area relationships, canopy transpiration and carbon gain of Norway spruce stands (Picea abies) in the Fichtelgebirge, Germany. Tree Physiology, 22(8), 567-574. doi:10.1093/treephys/22.8.567

Köstner, B. M. M., Schulze, E.-D., Kelliher, F. M., Hollinger, D. Y., Byers, J. N., Mcseveny, T. M., Meserth, R., Weir, P. L. (1992). Transpiration and Canopy Conductance in a Pristine Broad-Leaved Forest of Nothofagus : An Analysis of Xylem Sap Flow and Eddy Correlation Measurements. Oecologia, 91(3), 350-359.

Kozlowski, T. T. (Ed.). (1981). Water Deficits and Plant Growth. In Woody Plant Communities (Vol. VI). Academic Press. doi:10.1086/640981

Li, C. W., \& Barnes, I. W. (1980). The Relationship Between Net and Global Radiation Over Water. Archives for Meteorology, Geophysics and Climatology, Ser. B, 28, 91-100.

Litvak, E., Bijoor, N. S., \& Pataki, D. E. (2014). Adding trees to irrigated turfgrass lawns may be a water-saving measure in semi-arid environments. Ecohydrology, 7(5), 1314-1330. doi:10.1002/eco.1458

Litvak, E., McCarthy, H. R., \& Pataki, D. E. (2011). Water relations of coast redwood planted in the semi-arid climate of southern California. Plant, Cell \& Environment, 34(8), 1384-400. doi:10.1111/j.1365-3040.2011.02339.x

Litvak, E., McCarthy, H. R., \& Pataki, D. E. (2012). Transpiration sensitivity of urban trees in a semi-arid climate is constrained by xylem vulnerability to cavitation. Tree Physiology, 32, 
373-388. doi:10.1093/treephys/tps015

MacDonald, G. M. (2010). Water, climate change, and sustainability in the southwest.

Proceedings of the National Academy of Sciences of the United States of America, 107(50), 21256-21262. doi:10.1073/pnas.0909651107

Marková, I., Janouš, D., \& Marek, M. V. (2006). TOTAL NET RADIATION OF THE MOUNTAIN NORWAY SPRUCE STAND AT BÍLÝ KŘÍŽ (THE CZECH REPUBLIC). Ekológia (Bratislava), 25(4), 352-365.

Martínez-Vilalta, J., Vanderklein, D., \& Mencuccini, M. (2007). Tree height and age-related decline in growth in Scots pine (Pinus sylvestris L.). Oecologia, 150(4), 529-544. doi:10.1007/s00442-006-0552-7

McCarthy, H. R., \& Pataki, D. E. (2010). Drivers of variability in water use of native and nonnative urban trees in the greater Los Angeles area. Urban Ecosystems, 13(4), 393-414. doi:10.1007/s11252-010-0127-6

McCarthy, H. R., Pataki, D. E., \& Jenerette, G. D. (2011). Plant water-use efficiency as a metric of urban ecosystem services. Ecological Applications, 21(8), 3115-3127.

Melillo, J. M., Richmond, T. C., \& Yohe, G. W. (Eds.). (2014). Climate Change Impacts in the United States: The Third National Climate Assessment. Washington, DC: U.S. Global Change Research Program. doi:10.7930/J0Z31WJ2

Mini, C., Hogue, T. S., \& Pincetl, S. (2014). Estimation of residential outdoor water use in Los Angeles, California. Landscape and Urban Planning, 127, 124-135. doi:10.1016/j.landurbplan.2014.04.007

Monteith, J. L. (1965). Evaporation and environment. Symosia of the Society for Experimental 
Biology, 19, 205-234.

Ngo, N. S., \& Pataki, D. E. (2008). The energy and mass balance of Los Angeles County. Urban Ecosystems, 11(2), 121-139. doi:10.1007/s11252-008-0051-1

Nowak, D. J., Hoehn, R. E. I., Crane, D. E., Weller, L., \& Davila, A. (2010). Assessing Urban Forest Effects and Values. Los Angeles Urban Forest. Delaware, OH: USDA Forest Service.

Oren, R., Sperry, J. S., Katul, G. G., Pataki, D. E., Ewers, B. E., Phillips, N., \& Schäfer, K. V. R. (1999). Survey and synthesis of intra- and interspecific variation in stomatal sensitivity to vapour pressure deficit. Plant, Cell \& Environment, 22(12), 1515-1526. doi:10.1046/j.1365-3040.1999.00513.x

Pataki, D. E., Boone, C. G., \& Hogue, T. S. (2011). Socio-ecohydrology and the urban water challenge. Ecohydrology, 347, 341-347. doi:10.1002/eco

Pataki, D. E., McCarthy, H. R., Gillespie, T., \& Generette, G. D. (2013). A trait-based ecology of the Los Angeles urban forest. Ecosphere, 4(6), 72.

Pataki, D. E., McCarthy, H. R., Litvak, E., \& Pincetl, S. (2011). Transpiration of urban forests in the Los Angeles metropolitan area. Ecological Applications, 21(3), 661-677.

Penman, H. (1948). Natural evaporation from open water, bare soil and grass. Proceedings of the Royal Society of London. Series A, Mathematical and Physical Sciences, 193(1032), 120145.

Pereira, L. S., \& Perrier, A. (1999). Evapotranspiration: concepts and future trends. Journal of Irrigation and Drainage Engineering, 125(2), 45-51.

Pincetl, S. (2010). Implementing municipal tree planting: Los Angeles million-tree initiative. 
Environmental Management, 45(2), 227-38. doi:10.1007/s00267-009-9412-7

Renninger, H. J., Phillips, N., \& Hodel, D. R. (2009). Comparative hydraulic and anatomic properties in palm trees (Washingtonia Robusta) of varying heights: implications for hydraulic limitation to increased height growth. Trees, 23(5), 911-921. doi:10.1007/s00468009-0333-0

Rim, C.-S. (2009). The effects of urbanization, geographical and topographical conditions on reference evapotranspiration. Climatic Change, 97(3-4), 483-514. doi:10.1007/s10584-0099618-y

Shields, C. A., \& Tague, C. L. (2012). Assessing the Role of Parameter and Input Uncertainty in Ecohydrologic Modeling: Implications for a Semi-arid and Urbanizing Coastal California Catchment. Ecosystems, 15, 775-791. doi:10.1007/s10021-012-9545-z

Sinclair, T. R., Wherley, B. G., Dukes, M. D., \& Cathey, S. E. (2014). Penman's sink-strength model as an improved approach to estimating plant canopy transpiration. Agricultural and Forest Meteorology, 197, 136-141.

Smith, D. M., \& Jarvis, P. G. (1998). Physiological and environmental control of transpiration by trees in windbreaks. Forest Ecology and Management, 105(1-3), 159-173. doi:10.1016/S0378-1127(97)00292-2

Spano, D., Snyder, R. L., Sirca, C., \& Duce, P. (2009). ECOWAT-A model for ecosystem evapotranspiration estimation. Agricultural and Forest Meteorology, 149(10), 1584-1596. doi:10.1016/j.agrformet.2009.04.011

Spronken-smith, R. A., Oke, T. R., \& Lowry, W. P. (2000). Advection and the surface energy balance across an irrigated urban park. International Journal of Climatology, 20, 1033- 
1047.

Thompson, A. (2016). El Niño is Here, But California Is Still in Drought. Scientific American.

Vahmani, P., \& Hogue, T. S. (2014a). High-resolution land surface modeling utilizing remote sensing parameters and the Noah UCM: a case study in the Los Angeles Basin. Hydrology and Earth System Sciences, 18(12), 4791-4806. doi:10.5194/hess-18-4791-2014

Vahmani, P., \& Hogue, T. S. (2014b). Incorporating an Urban Irrigation Module into the Noah Land Surface Model Coupled with an Urban Canopy Model. Journal of Hydrometeorology, 140421133412009. doi:10.1175/JHM-D-13-0121.1

Valladares, F., \& Niinemets, Ü. (2008). Shade Tolerance, a Key Plant Feature of Complex Nature and Consequences. Annual Review of Ecology, Evolution, and Systematics, 39(1), 237-257. doi:10.1146/annurev.ecolsys.39.110707.173506

Williams, A. P., Seager, R., Abatzoglou, J. T., Cook, B. I., Smerdon, J. E., \& Cook, E. R. (2015). Contribution of anthropogenic warming to California drought during 2012-2014. Geophysical Research Letters, 42, 6819-6828. doi:10.1002/2015GL064924

Zeppel, M. (2013). Convergence of tree water use and hydraulic architecture in water-limited regions: A review and synthesis. Ecohydrology, 6(5), 889-900. doi:10.1002/eco.1377

Zhang, J., Hart, Q., Gertz, M., Rueda, C., \& Bergamini, J. (2009). Sensor data dissemination systems using Web-based standards: a case study of publishing data in support of evapotranspiration models in California. Civil Engineering and Environmental Systems, 26(1), 35-52. doi:10.1080/10286600802003567 


\section{Tables}

\section{List of abbreviations}

Table 1 Site characteristics of measured tree stands including name, closest CIMIS weather station, tree species, diameter at breast height $(\mathrm{DBH})$, sapwood area $\left(A_{S}\right)$, planting density and site area. The closest CIMIS weather stations are listed along with distances to each site in parentheses (for more information about CIMIS weather stations, refer to www.cimis.water.ca.gov/stations.aspx). Number of trees, DBH and $A_{s}$ are shown for trees that had a significant relationship between transpiration $\left(E_{T}\right)$ and vapor pressure deficit of the air $\left(D_{T}\right)$ (Eq. 4 in the text). Four trees in total were excluded because of a lack of correlation between $E_{T}$ and $\ln \left(D_{T}\right)$ : one California sycamore at Irvine site 1, one laurel sumac at LA Zoo, one coast redwood tree at Irvine site 2, and one Canary Island pine at Police Academy. Planting density is shown for all trees that were studied at each site.

Table 2 Species factors $\left(k_{S}\right)$ recommended for the studied tree species in Los Angeles region from Costello et al. (2000), landscape coefficients for a tree planting density of 100 trees ha $^{-1}\left(k_{L}\right)$ calculated with regressions (Eq. 7 and Fig. 4), sapwood area specific landscape coefficients averaged for each species $\left(k_{L} / A_{S}\right)$, model coefficients $\left(E_{r e f}, m_{D}, \Delta E_{r e f}\right.$, and $\left.m_{I}\right) \pm$ one standard error of the regressions and $\mathrm{R}_{\mathrm{adj}}{ }^{2}$ (Eq. 8-10; $\mathrm{p} \leq 0.0009$ for all), and estimated decoupling coefficients $(\Omega)$. Site names are indicated for species measured at more than one location. $\mathrm{R}_{\mathrm{adj}}{ }^{2}$ for $k_{L}$ are shown in parentheses; standard errors of $k_{L}$ are less than 0.01 and not shown ( $\mathrm{p}<0.0001$ for all). Letters in parentheses indicate species water use: $\mathrm{H}$ - high, $\mathrm{M}$ - medium, and L - low. 
List of abbreviations

\begin{tabular}{|c|c|c|}
\hline Abbreviation & Units & Meaning \\
\hline $\mathrm{A}_{\mathrm{S}}$ & $\mathrm{cm}^{2}$ & Sapwood area \\
\hline CIMIS & & $\begin{array}{l}\text { California Irrigation Management Information System } \\
\text { (http://www.cimis.water.ca.gov) }\end{array}$ \\
\hline $\mathrm{D}$ & $\mathrm{kPa}$ & Vapor pressure deficit of the air measured by CIMIS weather stations \\
\hline$D_{T}$ & $\mathrm{kPa}$ & Vapor pressure deficit of the air measured within tree canopies \\
\hline $\mathrm{E}_{\mathrm{T}}$ & $\mathrm{kg} \mathrm{d}^{-1}$ & Transpiration of an individual tree \\
\hline $\mathrm{E}_{\mathrm{ref}}$ & $\mathrm{mm} \mathrm{d}^{-1}$ & $\begin{array}{l}\text { Transpiration of a single species tree stand with the density of } 100 \text { trees } \\
\text { ha }^{-1} \text { at daily average D of } 1 \mathrm{kPa} \text { (see eq. 8) }\end{array}$ \\
\hline $\mathrm{E}_{\text {Trees }}$ & $\mathrm{mm} \mathrm{d}^{-1}$ & $\begin{array}{l}\text { Transpiration of single species tree stands with the planting density of } \\
100 \text { trees }^{-1}\end{array}$ \\
\hline ET & $\mathrm{mm} \mathrm{d}^{-1}$ & Evapotranspiration (general term) \\
\hline $\mathrm{ET}_{0}$ & $\mathrm{~mm} \mathrm{~d}^{-1}$ & Reference evapotranspiration from CIMIS \\
\hline $\mathrm{I}_{0}$ & $\mathrm{~W} \mathrm{~m} \mathrm{~m}^{-2}$ & $\begin{array}{l}\text { Intensity of incoming solar radiation measured by CIMIS weather } \\
\text { stations }\end{array}$ \\
\hline $\mathrm{k}_{\mathrm{c}}$ & - & Crop coefficient (see eq. 2) \\
\hline$k_{L}$ & - & Landscape coefficient (see eq. 3 and 6) \\
\hline$k_{S}$ & - & Species-specific factor (see eq. 3) \\
\hline$m_{D}$ & $\begin{array}{l}\mathrm{mm} \mathrm{d}^{-1} \\
/ \ln (\mathrm{kPa})\end{array}$ & $\begin{array}{l}\text { Transpiration sensitivity of a single species tree stand with the density of } \\
100 \text { trees } \text { ha }^{-1} \text { to } D \text { (see eq. } 8 \text { ) }\end{array}$ \\
\hline$m_{I}$ & $\begin{array}{l}\mathrm{mm} \mathrm{d}^{-1} \\
\left(\mathrm{~W} / \mathrm{m}^{2}\right)\end{array}$ & $\begin{array}{l}\text { Transpiration sensitivity of a single species tree stand with the density of } \\
100 \text { trees }^{-1} \mathrm{a}^{-1} \text { to } \mathrm{I}_{0}\end{array}$ \\
\hline$m_{T}$ & $\begin{array}{l}\mathrm{mm} \mathrm{d}^{-1} / \\
\ln (\mathrm{kPa})\end{array}$ & Transpiration sensitivity of an individual tree to $D_{T}$ (see eq. 4 ) \\
\hline$\Delta \mathrm{E}_{\mathrm{ref}}$ & $\mathrm{mm} \mathrm{d}^{-1}$ & $\begin{array}{l}\text { Intercept of the linear relationship between the residuals of Eq. } 8 \text { and } I_{0} \\
\text { (see eq. 9) }\end{array}$ \\
\hline
\end{tabular}


Table 1

\begin{tabular}{|c|c|c|c|c|c|c|}
\hline Site & $\begin{array}{l}\text { CIMIS } \\
\text { weather } \\
\text { station } \\
\text { (distance to } \\
\text { site, } \mathrm{km} \text { ) }\end{array}$ & $\begin{array}{l}\text { Tree species } \\
\text { common names* } \\
\text { (number of trees) }\end{array}$ & $\begin{array}{l}\mathrm{DBH}, \mathrm{cm} \\
\text { inside } \\
\text { bark } \\
\pm \mathrm{SE}\end{array}$ & $\begin{array}{l}\text { As, } \mathrm{cm}^{2} \\
\pm \mathrm{SE}\end{array}$ & $\begin{array}{l}\text { Plantin } \\
\text { g } \\
\text { density, } \\
\text { trees/ha }\end{array}$ & $\begin{array}{l}\text { Area } \\
\text { of site, } \\
\mathrm{m}^{2}\end{array}$ \\
\hline $\begin{array}{l}\text { Irvine } \\
\text { site } 1\end{array}$ & $\begin{array}{l}\text { \#75 Irvine } \\
(12.8)\end{array}$ & $\begin{array}{l}\text { Canary Island pine (5) } \\
\text { California sycamore (4) }\end{array}$ & $\begin{array}{l}50.4 \pm 2.1 \\
45.8 \pm 5.1\end{array}$ & $\begin{array}{l}1678 \pm 89 \\
773 \pm 70\end{array}$ & 86 & 1166 \\
\hline $\begin{array}{l}\text { Irvine } \\
\text { site } 2\end{array}$ & $\begin{array}{l}\text { \#75 Irvine } \\
(12.6)\end{array}$ & $\begin{array}{l}\text { Rose gum (6) } \\
\text { Coast redwood (7) }\end{array}$ & $\begin{array}{l}64.7 \pm \\
10.8 \\
39.3 \pm 2.3\end{array}$ & $\begin{array}{l}622 \pm 144 \\
443 \pm 49\end{array}$ & 97 & 1441 \\
\hline Fullerton & $\begin{array}{l}\# 78 \\
\text { Pomona } \\
(19.9)\end{array}$ & Coast redwood (9) & $42.8 \pm 4.9$ & $460 \pm 64$ & 190 & 473 \\
\hline $\begin{array}{l}\text { LA Arboretum } \\
\text { site } 1\end{array}$ & $\begin{array}{l}\# 133 \\
\text { Glendale } \\
(17.3)\end{array}$ & $\begin{array}{l}\text { Kurrajong (9) } \\
\text { Lacebark tree (12) } \\
\text { Rose gum (4) }\end{array}$ & $\begin{array}{l}36.8 \pm 3.1 \\
51.0 \pm 5.8 \\
64.5 \pm 5.3\end{array}$ & $\begin{array}{l}297 \pm 32 \\
461 \pm 78 \\
666 \pm 91\end{array}$ & 105 & 2378 \\
\hline $\begin{array}{l}\text { LA Arboretum } \\
\text { site } 2\end{array}$ & $\begin{array}{l}\# 133 \\
\text { Glendale } \\
(17.0)\end{array}$ & $\begin{array}{l}\text { Blue jacaranda (3) } \\
\text { Crape myrtle (6) } \\
\text { Honey locust (3) } \\
\text { Goldenrain tree (4) } \\
\text { Chinese banyan (4) }\end{array}$ & $\begin{array}{l}28.5 \pm 3.2 \\
16.8 \pm 1.5 \\
43.6 \pm 5.4 \\
27.8 \pm 6.2 \\
31.1 \pm 2.0\end{array}$ & $\begin{array}{l}652 \pm 144 \\
231 \pm 42 \\
678 \pm 153 \\
451 \pm 129 \\
767 \pm 98\end{array}$ & 100 & 2007 \\
\hline Sycamore Ave & $\begin{array}{l}\text { \#99 Santa } \\
\text { Monica } \\
(12.8)\end{array}$ & $\begin{array}{l}\text { London planetree (4) } \\
\text { California sycamore (3) }\end{array}$ & $\begin{array}{l}50.3 \pm 7.6 \\
36.8 \pm 1.9\end{array}$ & $\begin{array}{l}905 \pm 159 \\
836 \pm 99\end{array}$ & 110 & 637 \\
\hline LA Zoo & $\begin{array}{l}\# 133 \\
\text { Glendale } \\
(7.6)\end{array}$ & $\begin{array}{l}\text { Blue jacaranda (6) } \\
\text { Laurel sumac (1) }\end{array}$ & $\begin{array}{l}14.1 \pm 1.6 \\
11.0 \pm 2.5\end{array}$ & $\begin{array}{l}167 \pm 41 \\
56.7 \pm 0.0\end{array}$ & 125 & 1198 \\
\hline $\begin{array}{l}\text { Police } \\
\text { Academy }\end{array}$ & $\begin{array}{l}\# 133 \\
\text { Glendale } \\
(12.7)\end{array}$ & $\begin{array}{l}\text { Chinese elm (5) } \\
\text { Canary Island pine (4) } \\
\text { Coast redwood (5) }\end{array}$ & $\begin{array}{l}26.6 \pm 2.1 \\
54.9 \pm 5.7 \\
35.1 \pm 6.1\end{array}$ & $\begin{array}{l}571 \pm 99 \\
1991 \pm 357 \\
398 \pm 118\end{array}$ & 222 & 675 \\
\hline
\end{tabular}

*Scientific names are listed in Table 2. 
Table 2

\begin{tabular}{|c|c|c|c|c|}
\hline \multirow{2}{*}{$\begin{array}{l}\text { Wood } \\
\text { porosity }\end{array}$} & \multicolumn{3}{|c|}{ Tree species } & \multirow{2}{*}{$k_{L}$} \\
\hline & Common name & Scientific name & Abb. & \\
\hline $\begin{array}{l}\text { Semi ring- } \\
\text { porous }\end{array}$ & Chinese banyan & Ficus microcarpa L. f. & FIMI & ns \\
\hline \multirow[t]{5}{*}{ Ring-porous } & Chinese elm & Ulmus parvifolia Jacq. & ULPA & $0.14(0.70)$ \\
\hline & Crape myrtle & Lagerstroemia indica $\mathrm{L}$. & LAIN & $0.11(0.50)$ \\
\hline & Goldenrain tree & Koelreuteria paniculata $\mathrm{Laxm}$. & KOPA & $0.17(0.56)$ \\
\hline & Honey locust & Gleditsia triacanthos $\mathrm{L}$. & GLTR & $0.21(0.09)$ \\
\hline & Laurel sumac & Malosma laurina (Nutt.) Nutt. Ex Abrams & MALA & ns \\
\hline \multirow[t]{2}{*}{ "Spongy"* } & Kurrajong & $\begin{array}{l}\text { Brachychiton populneus (Scott \& Endl.) R. } \\
\text { Br. }\end{array}$ & BRPO & $0.04(0.30)$ \\
\hline & Lacebark tree & Brachychiton discolor F. Muell. & BRDI & $0.06(0.21)$ \\
\hline \multirow[t]{4}{*}{$\begin{array}{l}\text { Diffuse- } \\
\text { porous }\end{array}$} & $\begin{array}{l}\text { Blue jacaranda } \\
\text { LA Zoo } \\
\text { LA Arboretum }\end{array}$ & Jacaranda mimosifolia D. Don & JAMI & $\begin{array}{l}\mathrm{ns} \\
\mathrm{ns}\end{array}$ \\
\hline & $\begin{array}{l}\text { California } \\
\text { sycamore } \\
\text { Sycamore Avenue } \\
\text { Irvine }\end{array}$ & Platanus racemosa Nutt. & PLRA & $\begin{array}{l}0.22(0.41) \\
0.10(0.49)\end{array}$ \\
\hline & London planetree & Platanus hybrida Brot. & PLHY & $0.33(0.50)$ \\
\hline & $\begin{array}{l}\text { Rose gum } \\
\text { Irvine } \\
\text { LA Arboretum }\end{array}$ & Eucalyptus grandis W. Hill ex Maiden & EUGR & $\begin{array}{l}\mathrm{ns} \\
\mathrm{ns}\end{array}$ \\
\hline \multirow[t]{2}{*}{ Coniferous } & $\begin{array}{l}\text { Canary Island } \\
\text { pine } \\
\text { Irvine } \\
\text { Police Academy }\end{array}$ & Pinus canariensis $\mathrm{C} . \mathrm{Sm}$. & PICA & $\begin{array}{l}0.14(0.41) \\
\mathrm{ns}\end{array}$ \\
\hline & $\begin{array}{l}\text { Cost redwood } \\
\text { Police Academy } \\
\text { Fullerton } \\
\text { Irvine }\end{array}$ & $\begin{array}{l}\text { Sequoia sempervirens } \\
\text { (D. Don) Endl. }\end{array}$ & SESE & $\begin{array}{l}0.03(0.42) \\
0.07(0.59) \\
0.05(0.56)\end{array}$ \\
\hline
\end{tabular}

* Sapwood of Brachychiton species is spongy and made entirely of wide vessels, which is different from other wood types (Choat et al., 2005). 
Table 2 (cont.)

\begin{tabular}{|c|c|c|c|c|c|c|c|}
\hline$k_{L} / A_{S}$ & $\begin{array}{l}\boldsymbol{k}_{\boldsymbol{S}} \\
\text { (Costello et al } \\
2000)\end{array}$ & $E_{r e f}$ & $m_{D}$ & $\Delta E_{r e f}$ & $m_{I}$ & $\mathbf{R}_{\text {adj }}^{2}$ & $\mathbf{\Omega}$ \\
\hline $\mathrm{ns}$ & $0.4-0.6(\mathrm{M})$ & $1.06 \pm 0.01$ & $0.17 \pm 0.02$ & $-0.48 \pm 0.05$ & $(2.0 \pm 0.2) \times 10^{-3}$ & 0.55 & 0.02 \\
\hline $2.4(\mathrm{M})$ & $0.4-0.6(\mathrm{M})$ & $0.52 \pm 0.01$ & $0.10 \pm 0.02$ & $-0.20 \pm 0.03$ & $(1.3 \pm 0.1) \times 10^{-3}$ & 0.41 & 0.04 \\
\hline $4.8(\mathrm{H})$ & - & $0.49 \pm 0.01$ & $0.08 \pm 0.01$ & $-0.27 \pm 0.02$ & $(1.2 \pm 0.1) \times 10^{-3}$ & 0.59 & 0.02 \\
\hline $3.8(\mathrm{H})$ & $0.1-0.3(\mathrm{~L})$ & $0.74 \pm 0.02$ & $0.10 \pm 0.02$ & $-0.47 \pm 0.05$ & $(2.1 \pm 0.2) \times 10^{-3}$ & 0.40 & 0.03 \\
\hline $3.1(\mathrm{H})$ & - & $0.97 \pm 0.01$ & $0.10 \pm 0.02$ & $-0.32 \pm 0.04$ & $(1.4 \pm 0.2) \times 10^{-3}$ & 0.29 & 0.02 \\
\hline $\mathrm{ns}$ & $<0.1(\mathrm{~L})$ & $0.03 \pm 0.00$ & $0.01 \pm 0.00$ & $0.01 \pm 0.00$ & $-(4.0 \pm 0.8) \times 10^{-5}$ & 0.29 & 0 \\
\hline $1.2(\mathrm{~L})$ & $0.1-0.3(\mathrm{~L})$ & $0.15 \pm 0.00$ & $0.04 \pm 0.00$ & $-0.05 \pm 0.01$ & $(0.2 \pm 0.0) \times 10^{-3}$ & 0.47 & 0 \\
\hline $1.3(\mathrm{~L})$ & $0.1-0.3(\mathrm{~L})$ & $0.25 \pm 0.01$ & $0.08 \pm 0.01$ & $-0.10 \pm 0.02$ & $(0.5 \pm 0.1) \times 10^{-3}$ & 0.44 & 0.01 \\
\hline ns & $0.4-0.6(\mathrm{M})$ & $\begin{array}{l}0.12 \pm 0.00 \\
0.88 \pm 0.02\end{array}$ & $\begin{array}{l}0.03 \pm 0.00 \\
0.25 \pm 0.02\end{array}$ & $\begin{array}{l}0.01 \pm 0.00 \\
\mathrm{~ns}\end{array}$ & $\begin{array}{l}-(0.1 \pm 0.0) \times 10^{-3} \\
\text { ns }\end{array}$ & $\begin{array}{l}0.41 \\
0.39\end{array}$ & $\begin{array}{l}0 \\
0.01\end{array}$ \\
\hline $2.0(\mathrm{M})$ & $0.4-0.6(\mathrm{M})$ & $\begin{array}{l}1.10 \pm 0.02 \\
0.51 \pm 0.01\end{array}$ & $\begin{array}{l}0.32 \pm 0.02 \\
0.20 \pm 0.02\end{array}$ & $\begin{array}{l}-0.53 \pm 0.03 \\
-0.19 \pm 0.04\end{array}$ & $\begin{array}{l}(2.3 \pm 0.1) \times 10^{-3} \\
(0.8 \pm 0.2) \times 10^{-3}\end{array}$ & $\begin{array}{l}0.84 \\
0.59\end{array}$ & $\begin{array}{l}0.03 \\
0.01\end{array}$ \\
\hline $3.7(\mathrm{H})$ & $0.4-0.6(\mathrm{M})$ & $1.63 \pm 0.05$ & $0.47 \pm 0.05$ & $-1.02 \pm 0.07$ & $(4.4 \pm 0.3) \times 10^{-3}$ & 0.68 & 0.06 \\
\hline $\mathrm{ns}$ & $0.4-0.6(\mathrm{M})$ & $\begin{array}{l}0.15 \pm 0.00 \\
0.57 \pm 0.01\end{array}$ & $\begin{array}{l}0.04 \pm 0.00 \\
0.12 \pm 0.01\end{array}$ & $\begin{array}{l}0.01 \pm 0.00 \\
-0.26 \pm 0.04\end{array}$ & $\begin{array}{l}-(0.1 \pm 0.0) \times 10^{-3} \\
(1.2 \pm 0.2) \times 10^{-3}\end{array}$ & $\begin{array}{l}0.45 \\
0.41\end{array}$ & $\begin{array}{l}0 \\
0.02\end{array}$ \\
\hline $0.9(\mathrm{~L})$ & $0.1-0.3(\mathrm{~L})$ & $\begin{array}{l}0.57 \pm 0.02 \\
0.39 \pm 0.01\end{array}$ & $\begin{array}{l}0.13 \pm 0.02 \\
0.03 \pm 0.01\end{array}$ & $\begin{array}{l}-0.27 \pm 0.03 \\
\mathrm{~ns}\end{array}$ & $\begin{array}{l}(1.5 \pm 0.1) \times 10^{-3} \\
\mathrm{~ns}\end{array}$ & $\begin{array}{l}0.53 \\
0.05\end{array}$ & $\begin{array}{l}0.04 \\
0\end{array}$ \\
\hline $1.1(\mathrm{~L})$ & $0.7-0.9(\mathrm{H})$ & $\begin{array}{l}0.11 \pm 0.00 \\
0.30 \pm 0.00 \\
0.23 \pm 0.00\end{array}$ & $\begin{array}{l}0.01 \pm 0.00 \\
0.11 \pm 0.01 \\
0.05 \pm 0.00\end{array}$ & $\begin{array}{l}-0.05 \pm 0.01 \\
-0.08 \pm 0.01 \\
-0.11 \pm 0.01\end{array}$ & $\begin{array}{l}(0.3 \pm 0.0) \times 10^{-3} \\
(0.4 \pm 0.0) \times 10^{-3} \\
(0.5 \pm 0.0) \times 10^{-3}\end{array}$ & $\begin{array}{l}0.19 \\
0.80 \\
0.70\end{array}$ & $\begin{array}{l}0.01 \\
0.01 \\
0.01\end{array}$ \\
\hline
\end{tabular}




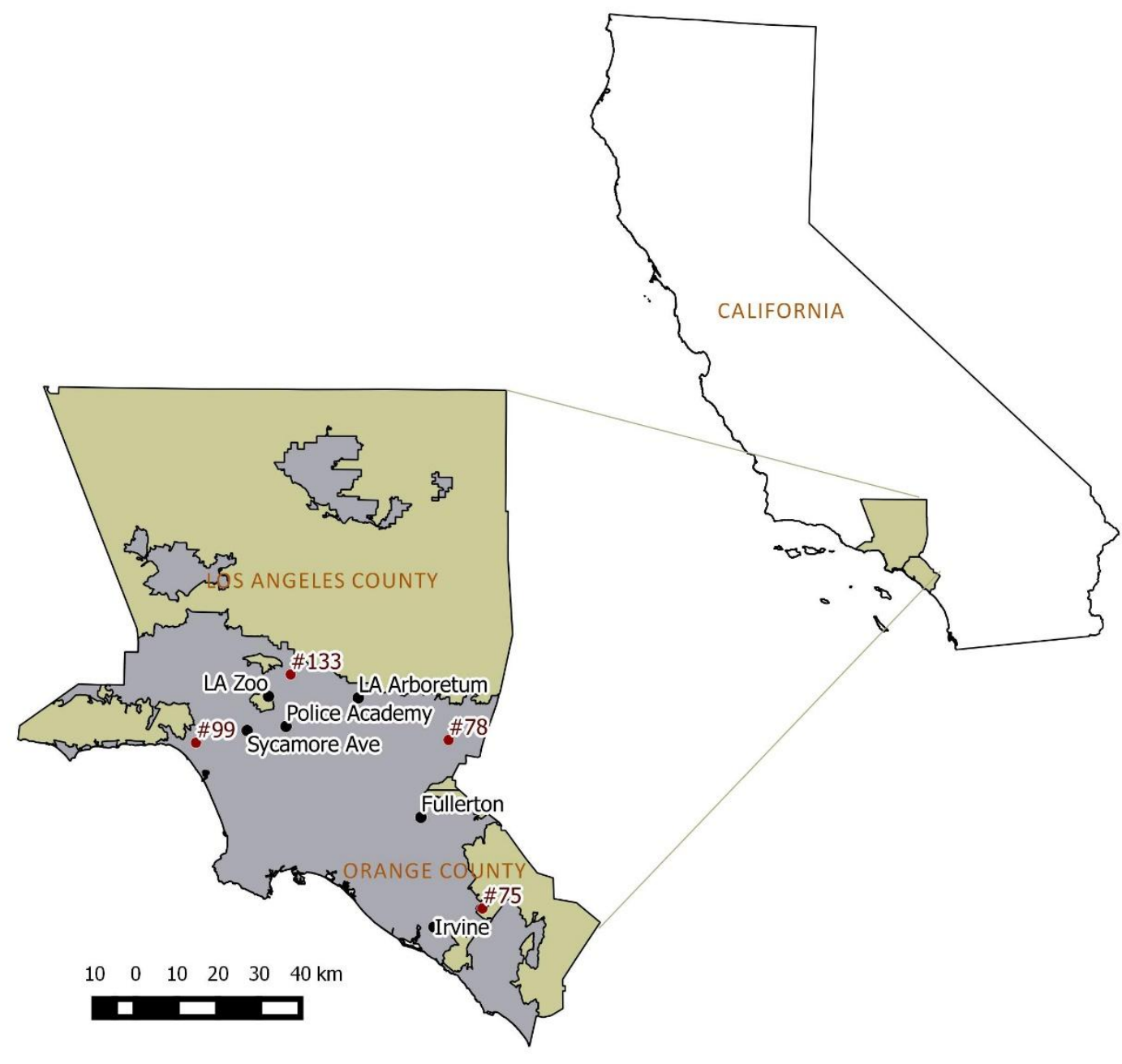

Figure 1 Location of study sites (black circles) and closest CIMIS weather stations (red circles). Study sites were located in urbanized parts of Los Angeles and Orange Counties in California (highlighted in grey according to www.census.gov). 


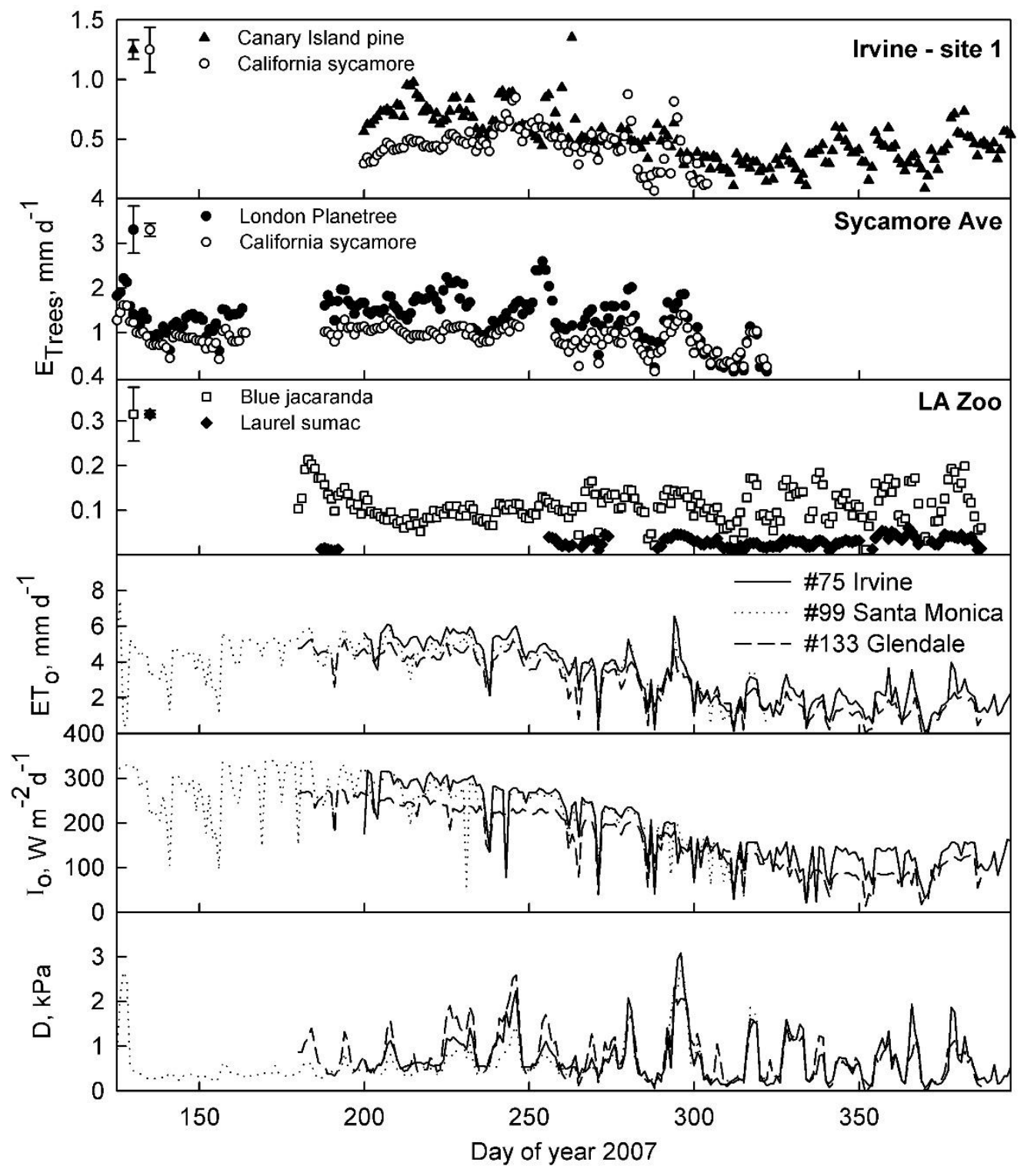


Figure 2 Daily tree transpiration $\left(E_{\text {Trees }}\right)$ measured in 2007 and corresponding environmental data from CIMIS weather stations: daily reference evapotranspiration $\left(E T_{0}\right)$, incoming solar radiation $\left(I_{0}\right)$ and vapor pressure deficit of the air $(D) . E_{\text {Trees }}$ represents transpiration of single species stands with planting density of 100 trees $\mathrm{ha}^{-1}$. Note the different scales of $\mathrm{y}$-axes for different study locations. Error bars are shown separately from data points for clarity and represent an average propagated standard error that includes uncertainty of sap flux measurements and $E_{\text {Trees }}$ calculations. 


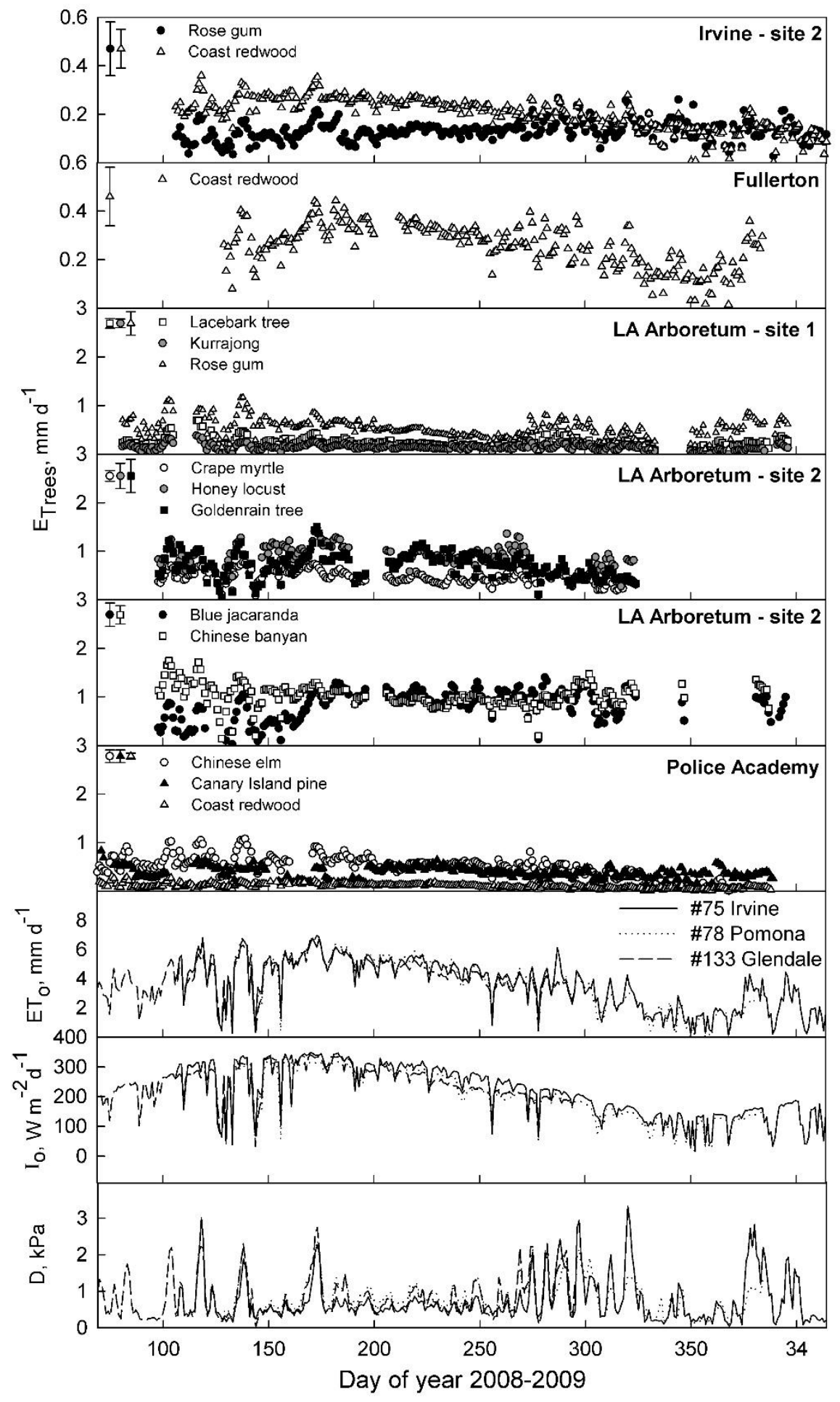

Figure 3 Daily tree transpiration $\left(E_{\text {Trees }}\right)$ measured in 2008 and corresponding environmental data from CIMIS weather stations: daily $E T_{0}, I_{0}$ and $D . E_{\text {Trees }}$ represents transpiration of single 
species stands with planting density of 100 trees $\mathrm{ha}^{-1}$. Note the different scales of $\mathrm{y}$-axes for different study locations. Error bars are shown separately from data points for clarity and represent an average propagated standard error that includes uncertainty of sap flux measurements and $E_{\text {Trees }}$ calculations. 


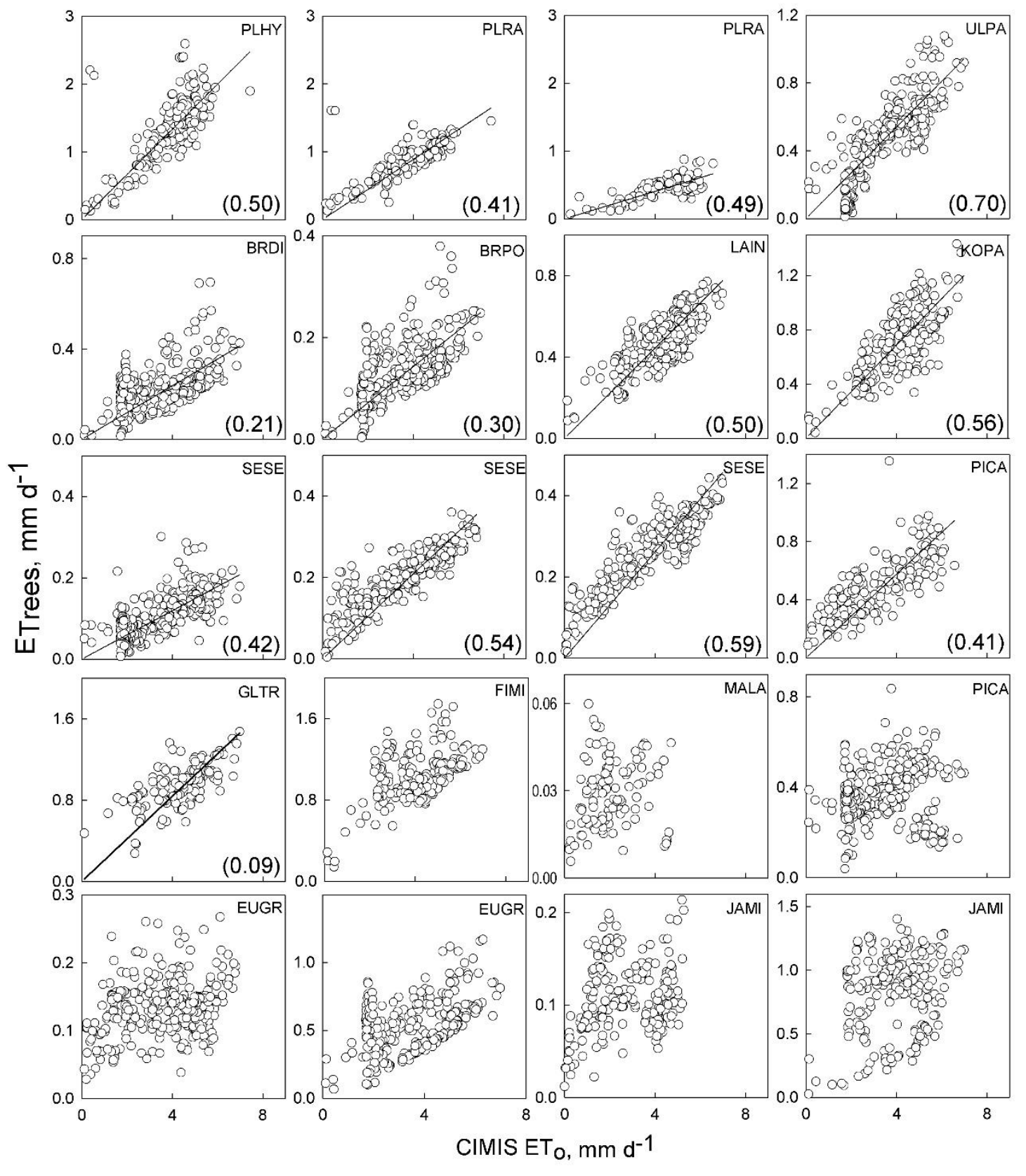

Figure 4 Transpiration of urban trees $\left(E_{\text {Trees }}\right)$ versus CIMIS reference evapotranspiration $\left(E T_{0}\right)$.

Regression lines are shown where significant. $\mathrm{R}_{\mathrm{adj}}{ }^{2}$ for regression lines are shown in parentheses; $\mathrm{p}<0.0001$ for all. The abbreviation on each panel corresponds to the species scientific name (shown in Table 2). Species and locations, from left to right $-1^{\text {st }}$ row: London planetree at 
Sycamore Ave, California sycamore at Sycamore Ave, California sycamore at Irvine and Chinese elm at Police Academy; $2^{\text {nd }}$ row: lacebark tree, kurrajong, crape myrtle and goldenrain tree, all at LA Arboretum; $3^{\text {rd }}$ row: coast redwood at Police Academy, coast redwood at Irvine, coast redwood at Fullerton and Canary Island pine at Irvine; $4^{\text {th }}$ row: honey locust at LA Arboretum, Chinese banyan at LA Arboretum, laurel sumac at LA Zoo and Canary Island pine at Police Academy; $5^{\text {th }}$ row: rose gum at Irvine, rose gum at LA Arboretum, blue jacaranda at LA Zoo and blue jacaranda at LA Arboretum. 


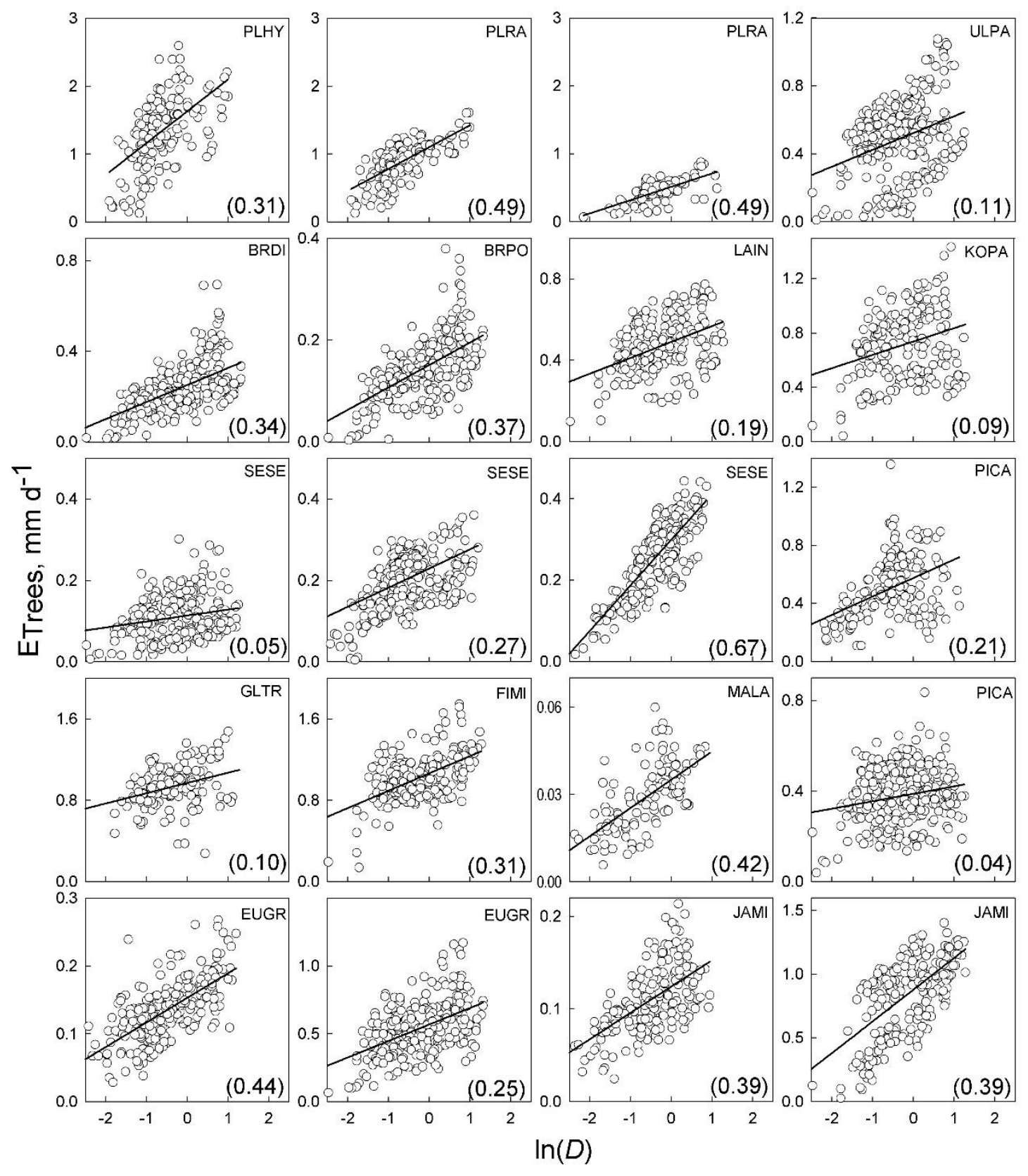

Figure 5 Transpiration of urban trees $\left(E_{\text {Trees }}\right)$ versus $\ln (D)$ (vapor pressure deficit of the air) at CIMIS weather stations. $\mathrm{R}_{\mathrm{adj}}{ }^{2}$ for regression lines are shown in parentheses; $\mathrm{p} \leq 0.0002$ for all. The abbreviation on each panel corresponds to the species scientific name (shown in Table 2). Species and locations, from left to right $-1^{\text {st }}$ row: London planetree at Sycamore Ave, California 
sycamore at Sycamore Ave, California sycamore at Irvine and Chinese elm at Police Academy; $2^{\text {nd }}$ row: lacebark tree, kurrajong, crape myrtle and goldenrain tree, all at LA Arboretum; $3^{\text {rd }}$ row: coast redwood at Police Academy, coast redwood at Irvine, coast redwood at Fullerton and Canary Island pine at Irvine; $4^{\text {th }}$ row: honey locust at LA Arboretum, Chinese banyan at LA Arboretum, laurel sumac at LA Zoo and Canary Island pine at Police Academy; $5^{\text {th }}$ row: rose gum at Irvine, rose gum at LA Arboretum, blue jacaranda at LA Zoo and blue jacaranda at LA Arboretum. 


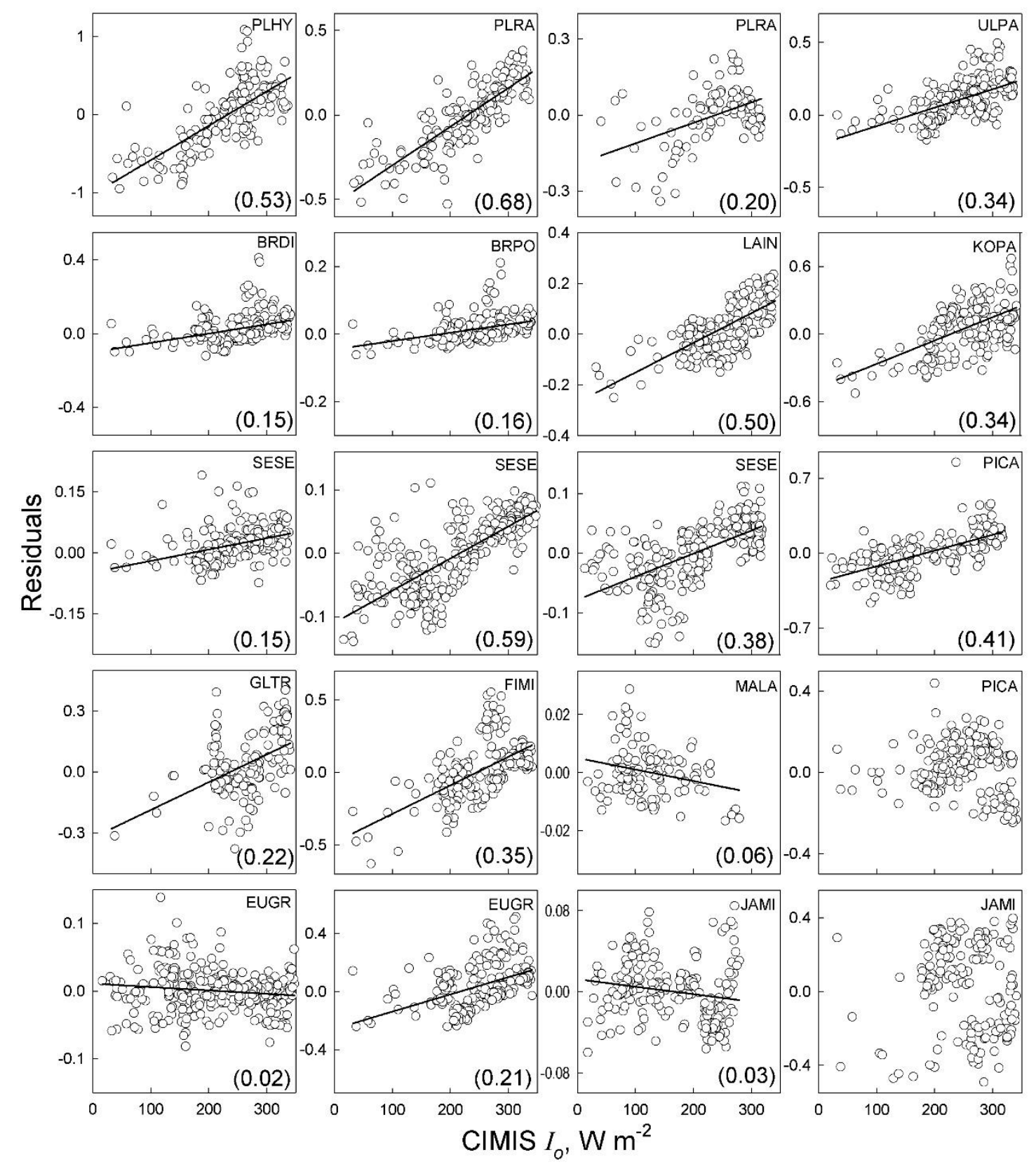

Figure 6 Residuals of Eq. 8 versus incoming solar radiation $\left(I_{0}\right)$ at CIMIS weather stations.

Regression lines are shown where significant. $\mathrm{R}_{\mathrm{adj}}{ }^{2}$ for regression lines are shown in parentheses;

$\mathrm{p}<0.02$ for all. The abbreviation on each panel corresponds to the species scientific name

(shown in Table 2). Species and locations, from left to right $-1^{\text {st }}$ row: London planetree at 
Sycamore Ave, California sycamore at Sycamore Ave, California sycamore at Irvine and Chinese elm at Police Academy; $2^{\text {nd }}$ row: lacebark tree, kurrajong, crape myrtle and goldenrain tree, all at LA Arboretum; $3^{\text {rd }}$ row: coast redwood at Police Academy, coast redwood at Irvine, coast redwood at Fullerton and Canary Island pine at Irvine; $4^{\text {th }}$ row: honey locust at LA Arboretum, Chinese banyan at LA Arboretum, laurel sumac at LA Zoo and Canary Island pine at Police Academy; $5^{\text {th }}$ row: rose gum at Irvine, rose gum at LA Arboretum, blue jacaranda at LA Zoo and blue jacaranda at LA Arboretum. 

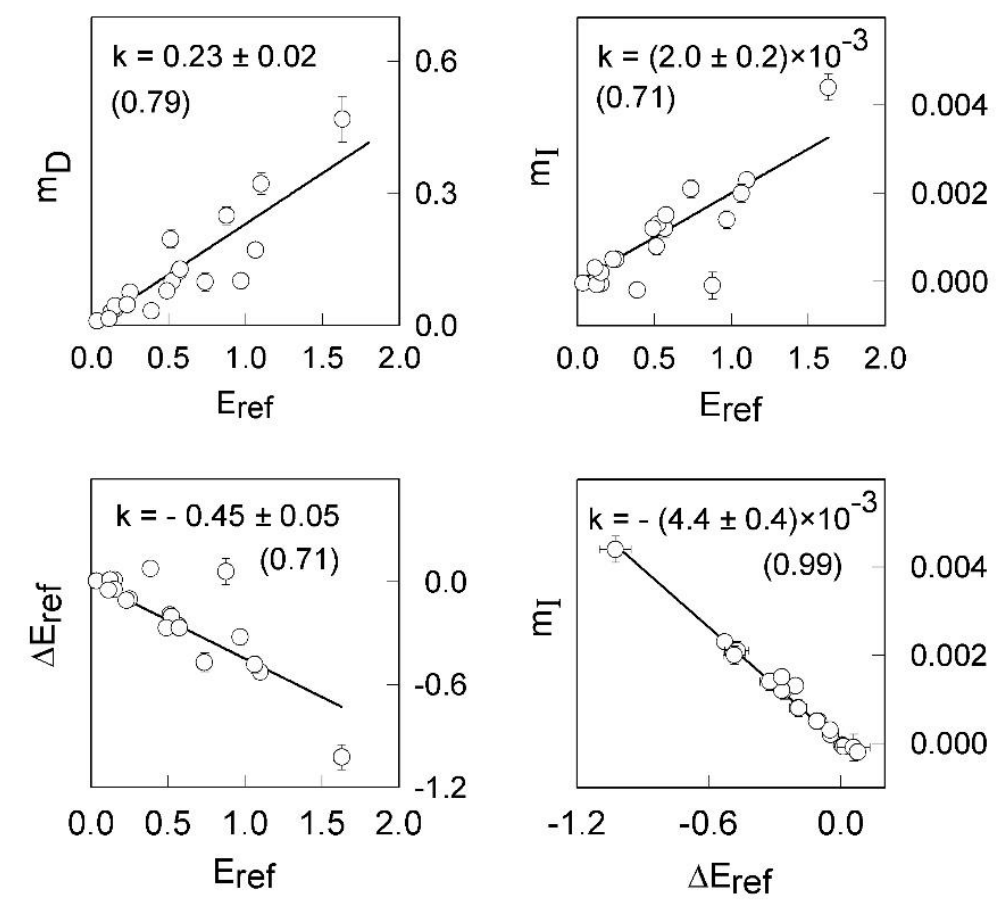

Figure $7 \mathrm{Model}$ coefficients $E_{r e f}$ (reference transpiration), $\Delta E_{r e f}$ (intercept term), $m_{D}$ (transpiration sensitivity to vapor pressure deficit) and $m_{I}$ (transpiration sensitivity to incoming solar radiation) from the equation $E_{\text {Trees }}=E_{\text {ref }}+m_{D} \ln D+\Delta E_{\text {ref }}+m_{I} I_{0}$ (Eq. 10 in the text), plotted against each other. The regression lines $y=k x$ are fitted and $\mathrm{R}_{\mathrm{adj}}{ }^{2}$ are shown in parentheses. $\mathrm{p}<0.0001$ for all. Error bars correspond to one standard error. 


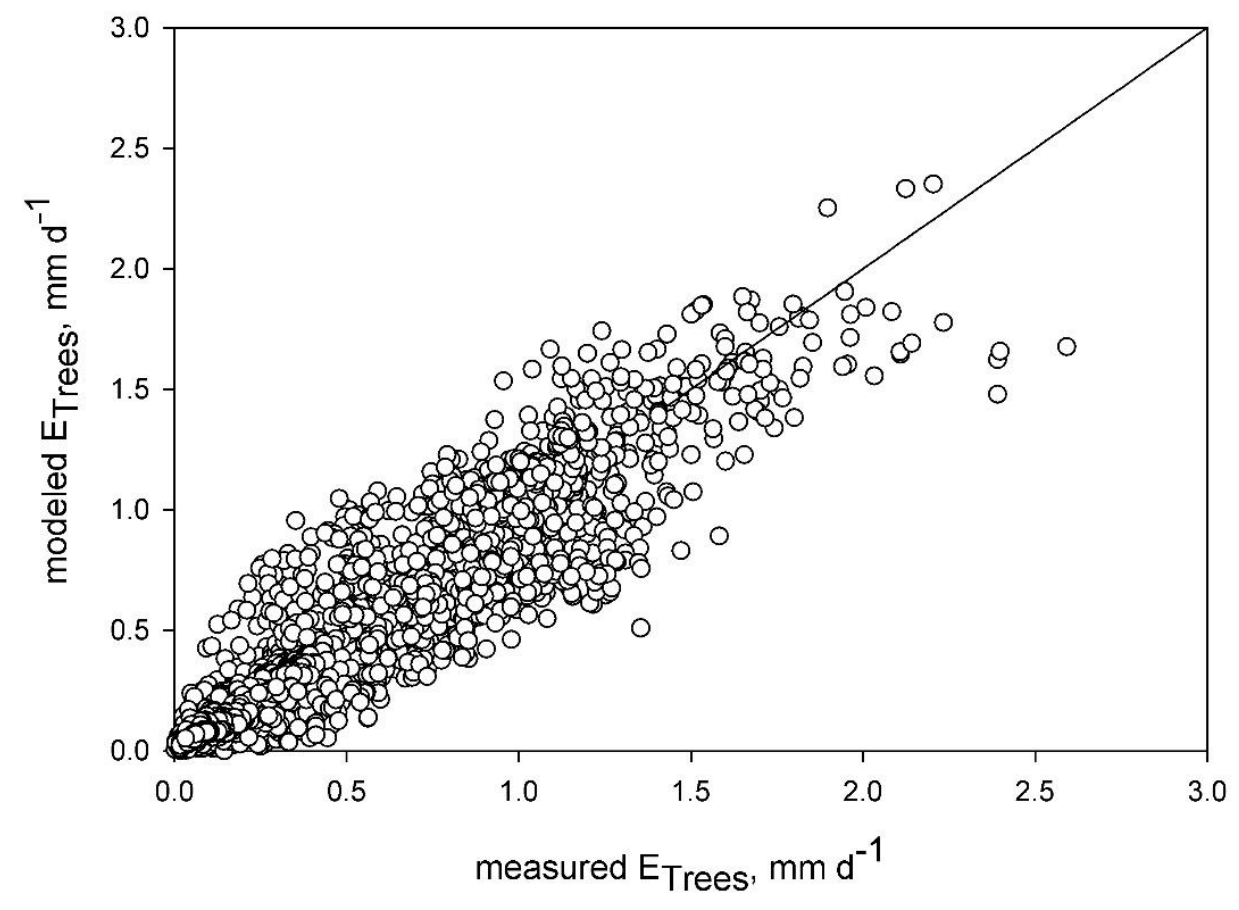

Figure 8 Tree transpiration $\left(E_{\text {Trees }}\right)$ versus modeled $E_{\text {Trees }}$ as $E_{\text {Trees }}=E_{\text {ref }}(0.55+0.23 \ln D+$ $0.002 I_{0}$ ) (Eq. 14 in the text), shown with 1:1 line. Data from all species and study sites are shown together (see Table 2 for $E_{\text {ref }}$ and $\mathrm{R}_{\text {adj }}{ }^{2} ; \mathrm{p} \leq 0.0009$ for all). 


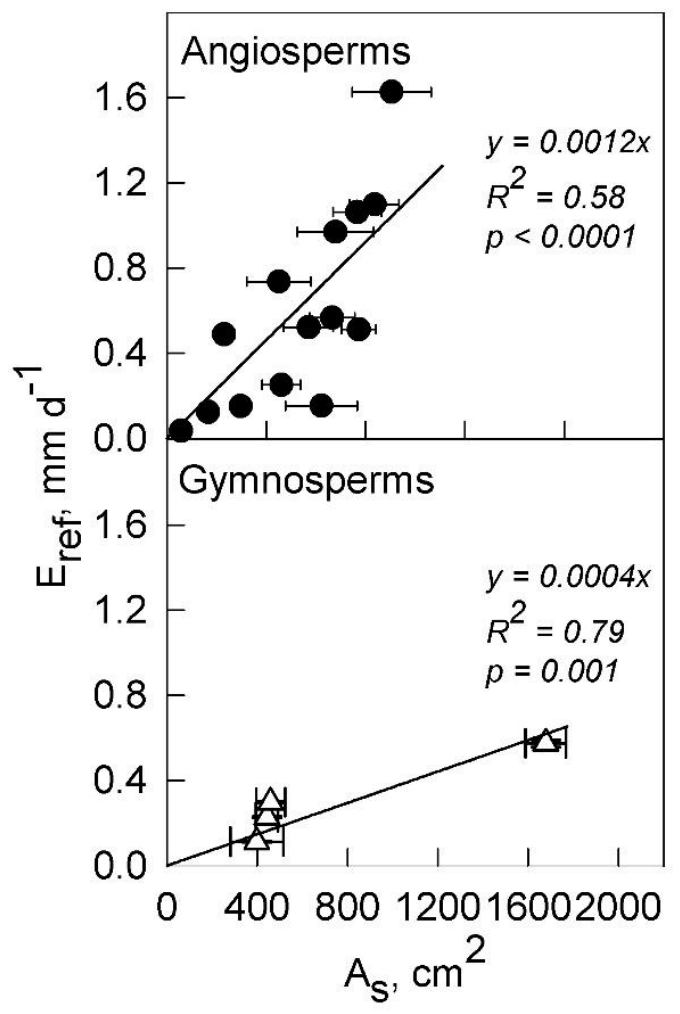

Figure 9 Reference transpiration $\left(E_{r e f}\right)$ as a function of sapwood area $\left(A_{S}\right)$. Angiosperm and gymnosperm trees shown on separate panels. The fitted linear functions (shown on the figure) are used to estimate $E_{\text {ref }}$ in the empirical model of tree transpiration (Eq. $15 \mathrm{a}$ and $\mathrm{b}$ in the text). 


\section{Acknowledgements}

This study was supported by U.S. National Science Foundation grants IOS 1147057 and

EAR 1204442. The original dataset used in this study was collected on the properties of UC

Irvine, the City of Los Angeles, the Los Angeles Zoo and Botanical Gardens, the Los Angeles

County Arboretum and Botanic Garden, the Los Angeles Police Academy, and Fullerton

Arboretum, with valuable assistance by Stephanie Pincetl, Neeta Bijoor, Thomas Gocke,

Christine Goedhart, Eric Nguyen, Sonja Djuricin, and Amy Townsend-Small. 